\title{
Worker Heterogeneity and the Popularity of the Minimum Wage Institution
}

\author{
GEORGE ECONOMIDES \\ Athens University of Economics and Business and CESifo * \\ THOMAS MOUTOS \\ Athens University of Economics and Business and CESifo
}

\begin{abstract}
This paper analyzes long run outcomes resulting from adopting a binding minimum wage. The model distinguishes between workers of heterogeneous ability, and capitalists who do all the saving, and it entails - relative to the perfectly competitive benchmark large output and employment losses (among the lowest-ability workers) from the imposition of moderately binding minimum wages. These effects arise not only because firms respond to the wage increase - relative to the static perfectly competitive benchmark - by moving upwards along a given labour demand curve, but also due to inward shifts of the labour demand curve as savers respond to decreases in the (net of taxes) rate of return on their savings by saving less, thus reducing the economy's steadystate capital stock. Nevertheless, and despite the large, long-run, declines in aggregate output, consumption, and the capital stock implied by this model, MW legislation can be beneficial for large segments of employed workers, as long as they do not have to provide generous welfare support to the low-ability workers that the MW prevents them from finding employment.
\end{abstract}

Keywords: Minimum wage; capital accumulation; heterogeneity; unemployment. JEL Classifications: E21; E24; E64; H23; J23

\section{Introduction}

Minimum wage legislation is one of the oldest government interventions in the labour market. However, throughout its history it has met with opposition by (many) economists. For example, Webb (1912) with reference to the imposition of a minimum wage in the Australian province of Victoria in 1896, mentions that it was opposed with familiar arguments, i.e. that

\footnotetext{
* We thank Costas Azariadis, Sarantis Kalyvitis, Margarita Katsimi, Theodore Palivos, as well as conference participants at the 2018 IMAEF conference for helpful comments and suggestions. We gratefully acknowledge the comments and advice of two referees that have improved the presentation of the paper. The usual disclaimer applies.

(C) 2019 George Economides and Thomas Moutos. Licensed under the Creative Commons Attribution - Noncommercial 3.0 Licence (http://creativecommons.org/licenses/by-nc/3.0/. Available at http://rofea.org.
} 
"it was "against the laws of Political Economy", that it would cause the most hardly pressed businesses to shut down, that it would restrict employment, that it would drive away Capital, that it would be cruel to the aged worker and the poor widow, that it could not be carried out in practice, and so on and so forth' (p. 973). ${ }^{1}$ Yet, Webb concluded, that in a few years the minimum wage institution was receiving such widespread support that '... no statesman, no economist, no political party nor any responsible newspaper of Victoria, however much a critic of details, ever dreams now of undoing the Minimum Wage Law itself' (p. 976).

Despite economists' warnings, the popularity of the minimum wage institution continues unabated a century later. In a recent (January 2014) Pew Research Center poll, 73\% of Americans supported a rise in the minimum wage to $\$ 10.10$ (per hour) from the current $\$ 7.25$ rate. Moreover, in a December 2013 Wall Street Journal poll, 63\% were in support of an increase to $\$ 10.10$, whereas $43 \%$ said they backed an increase to $\$ 12.50$ an hour, and $28 \%$ backed a $\$ 15$ wage. These figures reveal that if the question involved smaller increases in the minimum wage (e.g. to $\$ 9.00$ ) the support would be overwhelming. ${ }^{2}$ In Germany, one of the few countries which only recently (January 2015) introduced, for the first time, a (national) minimum wage, a survey of German managers, conducted for the Handelsblatt business newspaper in July 2013, showed that $57 \%$ wanted a mandatory minimum wage in the country. An hourly rate of $€ 8.88$ was considered suitable, which is higher than the $€ 8.50$ rate which came into force in January 2015.

During the last two decades the opposition of economists to the minimum wage institution has become less vociferous - possibly due to the large number of theoretical and empirical studies which have questioned the standard prediction of competitive models (and earlier empirical consensus ${ }^{3}$ ) that binding minimum wages result in employment losses. The first dent in the consensus came with Card and Krueger's (1994) study of the impact on fast-food employment of the 1992 increase in the New Jersey state minimum wage. Their finding of

\footnotetext{
${ }^{1}$ Webb mentions that the minimum wage initially applied to 'five specially "sweated" trades', and that by 1910 it had expanded its coverage to practically every trade. Moreover, he mentions that in many cases it came about with the willing acquiescence of the employers, who, as they told him, appreciated the fact that 'the Minimum Wage is fixed by law and therefore really forced on all employers: the security that the Act accordingly gives them against being undercut by the dishonest or disloyal competitors, who simply will not (in Victoria as in the Port of London) adhere to the Common Rules agreed upon by Collective Bargaining' (pp. 975-976).

${ }^{2}$ The poll also showed that support for the $\$ 10.10$ rate was broad, including $61 \%$ of those earning $\$ 75,000$ (per annum) or more and $68 \%$ of those earning $\$ 30,000$ or less.

${ }^{3}$ The consensus was captured by Brown et al. (1982, p. 524), who, on the basis of a six-volume report summarizing evidence for the United States and Canada, concluded that: for teenagers (ages 16-19), a 10 percent increase in the minimum wage reduced teen employment, most plausibly, between 1 and 3 percent; for young adults (ages 20-24), the employment impact is "negative and smaller than that for teenagers"; for adults, the "direction of the effect...is uncertain in the empirical work as it is in the theory."
} 


\section{ECONOMIDES, MOUTOS Worker Heterogeneity and Popularity of Minimum Wage}

"no evidence that the rise in New Jersey's minimum wage reduced employment at fast-food restaurants in the state (p. 796), caused a stir among economists and released a flurry of theoretical and empirical research (see e.g. Card and Krueger, 1995 and 2000; Machin and Manning, 1997; Neumark and Wascher, 2000 and 2008; Manning, 2003; Dickens and Manning, 2004; Dube et al., 2010; Allegretto et al., 2011; Neumark et al., 2014) which, to say the least, has not managed to re-establish the previous consensus.

The purpose of the present paper is not to join the debate about the likely employment effects of minimum wages. ${ }^{4}$ Its purpose is to examine, in a model with competitive features, whether minimum wages can be beneficial for workers in the long run, i.e. once we allow for the potential effects of minimum wages on capital accumulation. In competitive models with homogeneous labour and without capital accumulation (i.e. in a static framework), if, say a policymaker, wished to maximize aggregate workers' income (i.e. the wage bill), it would set the minimum wage at a level such that the wage elasticity of the labour demand curve is one. If at that wage level labour supply exceeded labour demand and some workers became unemployed, the trade union could, in principle, redistribute the maximized wage bill among all (employed and unemployed) workers and guarantee a higher income to all of them relative to the competitive case. ${ }^{5}$ However, in a dynamic framework, in which saving in the form of physical capital is allowed, the decrease in compensation to other factor owners (e.g. capitalists) which the imposition of a (binding) minimum wage generates, could reduce capital accumulation. This in turn could result in an inward shift of the labour demand curve, and therefore to a fall in aggregate labour income. This is the issue we investigate in this paper. Surprisingly, this issue has not been investigated before (to our knowledge), possibly because the emphasis of the debate was on whether the "textbook" (static) competitive model was a reasonable approximation of actual labour markets, and whether binding minimum wages could be implemented without employment losses in models with a fixed capital stock. $^{6}$

We deliberately adopt a bare bones perfectly competitive framework in our analysis. This is done not because we believe that the perfectly competitive framework would be the

\footnotetext{
${ }^{4}$ It bears noting that the debate about the employment effects of minimum wage increases does not imply disagreement among economists that significant disemployment effects will arise if minimum wages surpass some threshold; the disagreement was, and is, whether at its current level (or, its proposed level) the minimum wage is below or above that threshold (see, e.g. Card and Krueger, 1995).

${ }^{5}$ If the comparison was made in utility terms, the increase in utility would be even higher since, in principle, some (or, all of the workers in the case of work-sharing) would be able to enjoy more leisure.

${ }^{6}$ Another strand of the literature on minimum wages has investigated whether minimum wages are an efficient redistributive tool and whether other more efficient methods of supporting persons with lowearning ability can be devised (see, e.g. Allen, 1987).
} 
"natural" outcome in the absence of minimum wages - after all, political institutions, government policies and regulations have a discernible impact on the so-called "market" outcomes. (Thus, outcomes that appear like 'natural' market allocations may in fact be the result of political decisions, or indeed of deliberate policy inaction.) It is also done not because we wish to ignore the various arguments that have been put forward in order to explain the possibly benign influence of minimum wages on employment, growth, or welfare. ${ }^{7}$ We do it because we wish to use a first-best benchmark and to ensure the disemployment effects of minimum wages, since in the opposite case the increase in aggregate labour income would be, trivially, guaranteed.

Our only point of departure from the conventional labour market model is in assuming that workers are heterogeneous in ability. Starting with Mirlees (1971), this is a standard feature of the optimal taxation literature in public finance. ${ }^{8}$ However, our paper departs from this literature in two ways. First, we introduce capital accumulation (see, e.g. Judd, 1985; Chamley, 1986; Acemoglu, 2009) and second, we distinguish between workers, who work but do not save, and capitalists who save but do not work. This is important since we allow the wage rate per unit of ability to be endogenously determined in the labour market. More specifically, we assume that workers differ in their endowment of effective labour supply (i.e., ability), which is in turn reflected in differences in labour income across workers. Minimum wages - which are set per unit of time rather than per effective unit of labour induce redistribution from the low- ability workers that cannot find a job due to the wage floor, ${ }^{9}$ to the rest of the workers. This is because minimum wages drive the low ability workers out of employment, thus raising the marginal product and the wages (per effective unit of labour) of employed workers. As a consequence, and to the extent that minimum wages impact on capital accumulation, we are able to take into account an additional effect of minimum wages, which works through shifting inwardly the traditional static labour demand curve.

${ }^{7}$ It has long been recognized (e.g. Robinson, 1933) that for the imposition of minimum wages to have beneficial effects on workers' welfare, firms must face imperfectly elastic labour supply curves; this could arise either due to monopsony power or due to the presence of efficiency wage considerations in which case "labour supply" would refer to effective units of labour (see, e.g. Rebitzer and Taylor, 1995; Manning, 1995; Manning, 2003).

${ }^{8}$ For applications of these type of models to the minimum wage debate, from an optimal taxation perspective, see Allen (1987), Guesnerie and Roberts (1987), Marceau and Boadway (1994), and Boadway and Cuff (2001). The latter paper shows that a minimum wage policy combined with forcing non-working welfare recipients to look for jobs (and accept job offers) can increase the amount of redistribution from those working to those not working, and possibly reduce unemployment.

${ }^{9}$ For political economy models which emphasize this feature in a static framework, see, e.g. Saint-Paul (2000), and Adam and Moutos (2011). 


\section{ECONOMIDES, MOUTOS Worker Heterogeneity and Popularity of Minimum Wage}

Throughout the paper we adopt a CES specification for technology, which allows changes in factor prices to affect factor shares but necessitates the use of numerical solutions. ${ }^{10} \mathrm{We}$ develop the model and derive the results in stages. In Section 2, we assume a comprehensive linear tax on all sources of income with the exception of welfare benefits for the unemployed. Using a wide variety of plausible parameter values, in Section 3 we show that it is possible, under decreasing returns to scale and linear taxation, for the after-tax incomes of all employed workers to increase under a minimum-wage regime ${ }^{11}$ but only if the unemployed receive welfare payments significantly smaller than what their incomes would be in the competitive case. In other words, it is impossible for the minimum-wage regime to increase the after-tax aggregate income of (employed cum unemployed) workers. Moreover, (all) employed workers can become better-off through the imposition of a minimum wage only by making the low-ability workers worse-off (in terms of after-tax income). ${ }^{12}$ The effects of minimumwage legislation thus match with what Stigler (1970) termed Director's Law - according to which public interventions are made for the primary benefit of the middle classes, and financed with taxes which are borne in considerable part by the (rich) capitalists and the poor. $^{13}$

Since most actual tax systems do not resemble the linear tax system, we proceed in Section 4 to consider the effects of minimum wages under a variety of simple non-linear tax structures. The first variant involves a single tax rate on all sources of income, but, for labour income alone, any income below a threshold level goes untaxed. The resulting tax progressivity on labour income implies that not all employed workers benefit from the imposition of a minimum wage; workers of medium ability that remain employed and do not face high average tax rates can benefit even if the welfare support provided to the

\footnotetext{
${ }^{10}$ Adopting a Cobb-Douglas specification would not obviate the need for numerical simulations, although some analytical results could be established in this case for the case of linear taxation; for more details, see Economides and Moutos (2016).

${ }^{11}$ We consider both moderate and substantial increases in minimum wages relative to the perfectly competitive benchmark. We find that the political viability of the minimum wage regime decreases as it increases in size.

${ }^{12}$ Even though the unemployed are left with a lower income than in the absence of the minimum wage, it is possible that their utility is higher with the minimum wage - since they enjoy more leisure. In a model with two skill levels (low- and high-skill), and under the assumption of efficient job rationing (i.e. the incidence of unemployment is among the low-skill workers with the highest disutility of work), Lee and Saez (2012) demonstrate that a minimum wage is desirable if the government values redistribution toward low wage workers. Although we do not focus on welfare outcomes in the present paper, it would be an interesting exercise to embed the Lee and Saez framework in a model with capital accumulation and study whether their results survive in a non-static framework.

${ }^{13}$ The (after-tax) income of capitalists declines since, first, their profits and capital holdings decrease, and, second, they have to contribute part of the tax revenue needed to finance the welfare transfers to the unemployed.
} 
unemployed (and the taxes required to finance it) is not meager. However, tax progressivity implies that workers at the high end of the ability distribution will see their (after-tax) incomes reduced if a minimum wage is implemented. If citizens express their policy preferences on the basis of their incomes alone, then a coalition against minimum wages can develop which involves low-ability workers (who shall become unemployed), high-ability workers (who shall face significantly higher tax rates), and the capitalists. Nevertheless, we show that for levels of welfare support at which no majority could be formed under linear taxation, this can be achieved under progressive taxation.

Other variants of progressive taxation discussed in Section 4 involve non-taxation of capital income (so as not to reduce the incentives for capital accumulation), along with different ways of apportioning the tax burden between labour income and profits. We find that excluding capital income from taxation does not increase the proportion of citizens in favour of the minimum wage. This is because, as in the previous cases, the capitalists and the unemployed remain against the minimum wage; but now the high-ability workers would have to shoulder a higher tax burden since capital income goes untaxed, thus reducing the threshold of ability above which (high-ability) workers would lose from the minimum wage. The importance of this effect appears to outweigh the beneficial effect on wage rates that higher capital accumulation could provide, thus reducing the political support for minimum wages.

In Section 5 we discuss further some politico-economic considerations which can increase the attractiveness of minimum wages to organized labour interests (or, to workers in general) despite the possible decrease in the aggregate level of income accruing to workers. The final section offers concluding comments and discusses some caveats of our analysis.

\section{The Basic Model}

We consider a closed economy producing a single good under perfectly competitive conditions. ${ }^{14}$ Capital and labour are the only factors used in the production of the good. We distinguish between workers and capitalists in two ways. First, capitalists save, whereas workers consume all their income in each period. ${ }^{15}$ Second, we assume that capitalists are a

\footnotetext{
${ }^{14}$ We do not analyse the case of imperfectly competitive product markets -which, in general, produces employment responses in response to the imposition of a binding minimum wage which are similar to the competitive case, since, it would require the use of a parameter value for the elasticity of the (aggregate) product demand curve for which no information exists.

${ }^{15}$ We note also that the presence of two distinct groups of agents is important in our framework since if the population consisted of just (heterogeneous) workers, then workers would no longer be able to extract a larger share of output without hurting themselves. This is because a rise in the wage rate earned by workers reduces the profits of the firms and the dividends received by the workers who are the sole owners of the firms. In this framework the inefficiency introduced by the minimum wage hurts the workers as there is no other group (i.e. the capitalists) on which the cost of inefficiency can be transferred to and from which workers can extract a larger share of output. Economides and Moutos (2016) provide an analysis of this issue in a Ramsey-type framework.
} 


\section{ECONOMIDES, MOUTOS Worker Heterogeneity and Popularity of Minimum Wage}

homogeneous group, but workers differ in ability. ${ }^{16}$ Since the latter feature is an important building block of our analysis, we start by describing this aspect of our model.

\subsection{The Perfectly Competitive Case}

\subsubsection{Workers}

There is a fixed number of workers in the economy, which we normalize to 1 . For all workerbased households (workers, thereafter) are assumed to have identical preferences (described below). However, workers differ in ability, as reflected in their endowment of effective number of labour units per unit of time (e.g. per hour, or day, or year). We assume that all workers have the same endowment of time units at their disposal (which we also normalize to 1), and that they supply inelastically their endowment of effective labour units. ${ }^{17}$ The distribution of effective labour units (ability) among workers is described by the Pareto distribution. Letting $e$ denote the ability of a worker, the Pareto distribution is defined over the interval $e \geq b$, and its $\mathrm{CDF}$ is

$$
F(e)=1-(b / e)^{\alpha}, \alpha>1, b>0
$$

Parameter $b$ stands for the lowest ability in the population of workers, and parameter $a$ determines the shape of the distribution (higher values of $a$ imply greater equality in the distribution of ability). The Pareto distribution, in addition to being easy to work with, is a relatively good approximation of actual income distributions (see, e.g. Creedy, 1997; Gabaix, 2016). The mean of the Pareto distribution is equal to,

$$
\mu=\alpha \beta /(\alpha-1)
$$

and the median ability of workers is

$$
m=2^{1 / \alpha} b
$$

Workers (denoted by the superscript $L$ ) are assumed to have intertemporally additive preferences of the form,

\footnotetext{
${ }^{16}$ Allowing capitalists to be a heterogeneous group may be an interesting extension of our model, but we do not pursue it here since it would not affect the qualitative nature of our results.

${ }^{17}$ Introducing the possibility of endogenous labour supply would be an interesting extension of the model. However, as shown in a different context by Economides and Moutos (2016), the existence of a variable labour supply is not crucial for determining the sign of the impact of the minimum wage on the after-tax wage rate.
} 
Review of Economic Analysis 1 (2019) 1-38

$$
U_{i}^{L}=\sum_{t=0}^{\infty} \beta^{t} \ln \left(C_{t, i}^{L}\right)
$$

where $0<\beta<1$ is the discount factor, and $C_{t, i}^{L}$ stands for worker's $i$ consumption at time $t$. Workers' incomes are equal to their labour earnings, which are equal to worker's ability times the wage per effective unit of labour, $e_{i} w_{t}$. We assume that workers consume in each period all of their current earnings. This assumption is not essential for our results and it can be motivated as an endogenous response of workers due to the presence of prohibitively large costs for their participation in the capital market; in contrast, these costs are lower for capitalists. The above imply that the consumption of workers evolves according to:

$$
C_{t, i}^{L}=e_{i} w_{t}
$$

\subsubsection{Capitalists}

There is a fixed number, $N$, of identical capitalists in the economy. ${ }^{18}$ In contrast to workers, they do not directly participate in production, but supply the capital used by firms and receive as dividends the firms' profits. ${ }^{19}$ For simplicity, and without loss of generality, we assume that the number of capitalists is equal to the number of firms. Their preferences ${ }^{20}$ are similar to workers', i.e.

$$
U^{K}=\sum_{t=0}^{\infty} \beta^{t} \ln \left(C_{t}^{K}\right)
$$

whereas their budget constraints are,

$$
C_{t}^{K}+K_{t+1}^{K}-(1-\delta) K_{t}^{K}=\Pi_{t}+r_{t} K_{t}^{K}
$$

In equation (6), $C_{t}^{K}$ stands for the consumption of each capitalist, and in equation (7), $K_{t}^{K}, r_{t} K_{t}^{K}$, and $\Pi_{t}$ stand for the capital stock, capital income, and profits accruing to each capitalist. Each capitalist is assumed to solve the following programme:

$$
\max _{C_{t}^{K}, K_{t+1}^{K}} \mathcal{L}=\sum_{t=0}^{\infty} \beta^{t}\left\{\ln C_{t}^{K}+\lambda_{t}\left(\Pi_{t}+r_{t} K_{t}^{K}-C_{t}^{K}-K_{t+1}^{K}+(1-\delta) K_{t}^{K}\right)\right\}
$$

\footnotetext{
${ }^{18}$ The share of capitalists in the population is thus equal to $N /(N+1)$.

${ }^{19}$ Following standard practice, and consistent with perfectly competitive behavior, we assume that each capitalist does not have a general equilibrium awareness of his actions when choosing how much capital to accumulate, i.e. he disregards any potential impact that his actions may have on the return to capital and on firms' profits.

${ }^{20}$ For convenience we drop the subscript pertaining to each capitalist since they are identical.
} 
The resulting first-order conditions are:

$$
\begin{gathered}
\lambda_{t}=1 / C_{t}^{K} \\
\lambda_{t}=\beta \lambda_{t+1}\left(r_{t+1}+1-\delta\right)
\end{gathered}
$$

Combining equations (8a) and (8b) we get:

$$
C_{t+1}^{K}=\beta\left(r_{t+1}+1-\delta\right) C_{t}^{K}
$$

Equation (9) summarizes the optimal consumption path for the capitalists, and (implicitly), along with their budget constraint, the supply of capital in the economy.

\subsubsection{Firms}

In this section we assume that firms' technology of converting inputs into output is represented by a generalized constant elasticity of substitution (CES) function ${ }^{21}$

$$
Y_{t}=\left[\theta\left(K_{t}^{f}\right)^{\rho}+(1-\theta)\left(L_{t}^{f}\right)^{\varrho}\right]^{v / \varrho}
$$

where $Y_{t}$ denotes output, $K_{t}^{f}$ is the capital stock used by the firm, $L_{t}^{f}$ is the number of effective units of labour used by the firm, $\rho \leq 1$ is a parameter governing the size of the elasticity of substitution between labour and capital, $\sigma$, with $\sigma \equiv 1 /(1-\rho)$, and $v<1$ implies decreasing returns to scale. Parameter $\theta \in(0,1)$ is a distribution parameter, which determines how important the labour and capital inputs are in the production process. We note that if $v=1$, and $\rho$ goes to zero, the production function converges to a constant-returns-to scale Cobb-Douglas one.

Firms maximize profits by choosing the appropriate use of capital and labour services, i.e. each firm,

$$
\max _{L_{t}^{f}, K_{t}^{f}} \Pi_{t}=Y_{t}-w_{t} L_{t}^{f}-r_{t} K_{t}^{f}
$$

subject to the constraint imposed by equation (10). The first order conditions for factor use are:

${ }^{21}$ The qualitative nature of our results does not largely depend on the chosen algebraic form of the production function, since, as discussed earlier (footnote 15) and in Section 3, the driving force behind our results is the presence of worker heterogeneity and the existence of another class of agents (capitalists) to which, along with the unemployed, the efficiency costs of minimum wages can be offloaded. 
Review of Economic Analysis 1 (2019) 1-38

$$
\begin{aligned}
& w_{t}=v(1-\theta)\left(L_{t}^{f}\right)^{\rho-1}\left[\theta\left(K_{t}^{f}\right)^{\rho}+(1-\theta)\left(L_{t}^{f}\right)^{\varrho}\right]^{(v-\varrho) / \varrho} \\
& r_{t}=v \theta\left(K_{t}^{f}\right)^{\rho-1}\left[\theta\left(K_{t}^{f}\right)^{\rho}+(1-\theta)\left(L_{t}^{f}\right)^{\varrho}\right]^{(v-\varrho) / \varrho}
\end{aligned}
$$

These imply that the profits accruing to each entrepreneur are:

$$
\Pi_{t}=(1-v) Y_{t}
$$

\subsubsection{Factor Market Equilibrium}

The aggregate supply of effective units of labour of all workers is found by the associated PDF of the Pareto distribution to be,

$$
L^{S}=\int_{b}^{\infty} e\left\{\alpha \frac{b^{\alpha}}{e^{\alpha+1}}\right\} d e=\frac{\alpha b}{\alpha-1}
$$

i.e., it is just equal to the mean units of effective labour times the number of workers (which we have normalized to 1). Labour market equilibrium obtains when the aggregate demand for labour by the $N^{K}$ firms is equal to aggregate labour supply, i.e. when,

$$
N^{K} L_{t}^{f}=\frac{\alpha b}{\alpha-1}
$$

Similarly, equilibrium in the capital market obtains when the total supply of capital - as provided by the capitalists - is equal to the demand for capital by firms, i.e. when

$$
K_{t}^{K}=K_{t}^{f}
$$

\subsubsection{General Equilibrium}

The dynamic behavior of the model is described by equations (5), (7), (9), (10), (11), (12), (13), (15), and (16), which, in long-run equilibrium, collapse to the following system (for ease of exposition we drop the time subscripts, and the superscripts distinguishing between capitalists and firms, since each firm is owned by a single capitalist, e.g. $L_{t}^{f}=L$ ):

$$
\begin{gathered}
C_{i}^{L}=e_{i} w \\
1=\beta(r+1-\delta) \\
C^{K}+\delta K=\Pi+r K \\
Y=\left[\theta(K)^{\rho}+(1-\theta)(L)^{\varrho}\right]^{v / \varrho}
\end{gathered}
$$


ECONOMIDES, MOUTOS Worker Heterogeneity and Popularity of Minimum Wage

$$
\begin{gathered}
\Pi=(1-v) Y \\
N^{K} L=\frac{\alpha b}{\alpha-1} \\
w=v(1-\theta)(L)^{\rho-1}\left[\theta(K)^{\rho}+(1-\theta)(L)^{\varrho}\right]^{(v-\varrho) / \varrho} \\
r=v \theta(K)^{\rho-1}\left[\theta(K)^{\rho}+(1-\theta)(L)^{\varrho}\right]^{(v-\varrho) / \varrho}
\end{gathered}
$$

Equations (LR2) -(LR8) determine the long-run equilibrium values of $w, r, K, L, Y, \Pi$, and $C^{K}$. We note that once the value of the wage rate is found we can determine the entire distribution of workers' consumption through equation (LR1).

More formally note that the right-hand-side (RHS) of Equation (LR2) is monotonic in $r$, and thus this equation determines a unique value of $r$. Similarly, Equation (LR6) uniquely determines $L$. We note that the RHS of Equation (LR8) is monotonic in $K$ for plausible parameter values ${ }^{22}$; thus, using the values for $r$ and $L$ previously determined, we can uniquely solve for $K$. Using the solutions for $L$ and $K$ into Equations (LR4) and (LR7)—which are also monotonic in their arguments - we can solve for the unique values of $Y$ and $w$, respectively. Given the solutions for $Y, K$ and $r$, equations (LR5) and (LR3) can each uniquely solve for $\Pi$, and $C^{K}$, respectively. Finally, note that once the value of the wage rate is found we can uniquely solve for the entire distribution of workers' consumption through equation (LR1).

\subsection{Minimum Wages}

We now assume the existence of a government-imposed minimum wage per unit of labour time (e.g. per hour) equal to $y$, which is the minimum amount that an employer must pay in order to employ one person. This minimum wage per unit of time must be distinguished from the wage rate per effective unit of labour, which will be market-determined (i.e. as in the previous section).

\subsubsection{Labour Market}

The minimum wage constraint implies that firms will not be willing to employ workers whose level of ability (i.e. number of efficient units of labour per unit of time) is such that:

$$
y>e_{i} \varpi_{t}
$$

where $\varpi_{t}$ stands for the market-determined wage rate per effective unit of labour in the

\footnotetext{
${ }^{22}$ See our discussion in Section 3.1.
} 
presence of the minimum-wage (per unit of time) constraint at time $t .{ }^{23}$ To avoid confusion in what follows we shall refer to the exogenously set, $y$, simply as the minimum wage, in order to differentiate it from the minimum wage rate, $\varpi_{t}$, and the competitive wage rate, $w$, both of which are endogenously determined. Let $\varepsilon_{t}$ denote the level of ability for which it holds that:

$$
y=\varepsilon_{t} \varpi_{t}
$$

It follows that only workers with $e_{i} \geq \varepsilon_{t}$ will be employed by firms, and that the individual with ability $\varepsilon_{t}$ will just earn the minimum wage, $y$. Workers with ability smaller than $\varepsilon_{t}$ will be unemployed, which implies that the unemployment rate is:

$$
u_{t}=1-\left\{\frac{b}{\varepsilon_{t}}\right\}^{\alpha}
$$

The total number of effective units of labour possessed (and supplied) by those individuals with $e_{i} \geq \varepsilon_{t}$ is,

$$
L^{S}=\int_{\varepsilon}^{\infty} e\left\{\alpha \frac{b^{\alpha}}{e^{\alpha+1}}\right\} d e=\frac{\alpha}{\alpha-1}\left\{\frac{b}{\varepsilon_{t}}\right\}^{\alpha} \varepsilon_{t}
$$

We can thus describe the condition describing equilibrium in the labour market (i.e. the analogue of equation (15) as:

$$
N^{K} L_{t}^{f}=\frac{\alpha}{\alpha-1}\left\{\frac{b}{\varepsilon_{t}}\right\}^{\alpha} \varepsilon_{t}
$$

A simple comparison of equations (15) and (20) reveals that -ceteris paribus- a binding minimum wage constraint, which implies that $b<\varepsilon$, will be associated with a higher wage rate per effective unit of labour than in its absence $(\varpi>w)$, due to the reduction in the aggregate effective units of labour supply caused by the exclusion of the lowest-ability workers from employment.

\subsubsection{Government}

In addition to setting (and enforcing) the minimum wage constraint, the government is assumed to levy a comprehensive linear income tax $(\tau)$ on all sources of income (with the exception of unemployment benefits), ${ }^{24}$ in order to finance benefits for the low-ability workers that are unemployed. This is a reasonable assumption in our context, since support

\footnotetext{
${ }^{23} \mathrm{We}$ assume that the minimum wage per unit of time is such that $y>b \varpi_{t}$.

${ }^{24}$ None of our results hinges on this assumption.
} 


\section{ECONOMIDES, MOUTOS Worker Heterogeneity and Popularity of Minimum Wage}

for those that the MW regime denies employment (and in this sense, the unemployed "deserve" public support) is a policy that no proponent of minimum wages would object to. We assume that the level of the unemployment benefit is a fixed proportion of the minimum wage, i.e. it is equal to $\phi y(0<\phi<1) .{ }^{25}$ Equation $(21)$, i.e. the government budget constraint, just states that the net payments to the unemployed are equal to the total tax receipts:

$$
\phi y u_{t}=\tau_{t} Y_{t}
$$

In what follows we shall assume that $\tau_{t}$ adjusts in every period so as to keep the government budget in balance.

\subsubsection{General Equilibrium}

The existence of taxes implies that equations (5), (7), and (9) must be modified to:

$$
\begin{gathered}
C_{t, i}^{L}=(1-\tau) e_{i} \varpi_{t} \\
C_{t}^{K}+K_{t+1}^{K}-(1-\delta) K_{t}^{K}=(1-\tau)\left(\Pi_{t}+r_{t} K_{t}^{K}\right) \\
C_{t+1}^{K}=\beta\left((1-\tau) r_{t+1}+1-\delta\right) C_{t}^{K}
\end{gathered}
$$

These three equations along with equations (16) - (21) describe the dynamic evolution of the system, whose long-run equilibrium is described by the following equations:

$$
\begin{aligned}
& C_{i}^{L}=(1-\tau) e_{i} \varpi \\
& 1=\beta((1-\tau) r+1-\delta) \\
& C^{K}+\delta K=(1-\tau)(\Pi+r K) \\
& Y=\left[\theta(K)^{\rho}+(1-\theta)(L)^{\varrho}\right]^{v / \varrho} \\
& \Pi=(1-v) Y \\
& N^{K} L=\frac{\alpha}{\alpha-1}\left\{\frac{b}{\varepsilon}\right\}^{\alpha} \varepsilon
\end{aligned}
$$

\footnotetext{
${ }^{25}$ This assumption implies that for persons with ability well below the threshold level of ability, $\varepsilon$, the level of unemployment benefits may exceed the income they would receive while employed in the absence of the minimum wage constraint. In the numerical simulations of the following sections we preclude this, by setting a low enough value for $\phi$.
} 
Review of Economic Analysis 1 (2019) 1-38

$$
\begin{gathered}
\varpi=v \theta(L)^{\rho-1}\left[\theta(K)^{\rho}+(1-\theta)(L)^{\varrho}\right]^{(v-\varrho) / \varrho} \\
r=v(1-\theta)(K)^{\rho-1}\left[\theta(K)^{\rho}+(1-\theta)(L)^{\varrho}\right]^{(v-\varrho) / \varrho} \\
u=1-\left\{\frac{b}{\varepsilon}\right\}^{\alpha} \\
y=\varepsilon \varpi \\
\phi y u=\tau Y
\end{gathered}
$$

These equations determine the long-run values of $\varpi, \varepsilon, r, u, K, L, Y, \Pi, C^{K}, C_{i}^{L}$, and $\tau$. We note that the system is no longer recursive, since equation (LR2a) does not uniquely solve for $r$. Moreover, due to the nonlinearity of the system, it is not possible to exclude theoretically the possibility of multiple equilibria. Nevertheless, we can report that after extensive numerical simulations with a wide range of plausible parameter values we have not found a single case of multiple equilibria. Nevertheless, we can draw some useful results by comparing the perfectly competitive (PC) with the minimum wage (MW) case.

\section{Comparison}

We now proceed to compare the equilibrium outcomes in the MW and PC cases, by focusing on long-run outcomes. ${ }^{26}$ Since it is impossible to derive closed-form solutions in the presence of the minimum- wage constraint, we resort to numerical calculations.

\subsection{Parameter values}

Table 1 reports the baseline parameter values for policy, technology and preferences used to obtain the long-run values of the endogenous variables. These values are similar to the ones used in macroeconomics (e.g. the business cycle literature). We set the baseline value of $\varrho$, which determines the degree of substitutability between capital and labour in production, to 0.1 . This implies that the elasticity of factor substitution, $\sigma\left(=\frac{1}{1-\varrho}\right)$, is equal to 0.909 , but we report also results for $\varrho=0.5$, and $\varrho=-2$, which imply that the elasticity of substitution is

\footnotetext{
${ }^{26}$ We note that in the MW case, wage rates (per effective unit of labour) during the transition will be higher than in the steady-state, due to the monotonic decline in the capital stock to its lower level. This implies that our focus on long-run outcomes alone - instead of including the transition path in our calculations - biases the comparison against the MW case. We abstain from reporting comparisons involving appropriately discounted values since they do not alter substantially the main implications of our analysis.
} 
ECONOMIDES, MOUTOS Worker Heterogeneity and Popularity of Minimum Wage

Table 1: Baseline parameterization

\begin{tabular}{|c||c|c|}
\hline Parameters & Description & Value \\
\hline \hline$\theta$ & Capital's share parameter in production function & 0.25 \\
\hline$\sigma$ & Elasticity of substitution between capital and labour & 0.909 \\
\hline $\mathbf{l}$ & Measure of returns to scale & 0.8 \\
\hline$\delta$ & Capital's depreciation rate & 0.08 \\
\hline$\beta$ & Rate of time preference & 0.98 \\
\hline $\mathrm{b}$ & Lowest ability in the population of workers & 1 \\
\hline$\alpha$ & Shape parameter of the Pareto distribution & 2 \\
\hline$\varphi$ & Welfare benefits replacement ratio (\% of minimum wage) & 0.35 \\
\hline$N^{k} /\left(N^{k}+N^{L}\right)$ & Share of capitalists in population & 0.30 \\
\hline
\end{tabular}

equal to 2 and 0.33 (respectively). Most empirical studies tend to find values for the elasticity of substitution which are smaller than 1 - but closer to 1 than to 0 (Antras, 2004); among the limited number of studies which presented elasticity estimates larger than 1 (e.g. Berndt, 1976), these were not statistically different from 1 - thus the other two values used for $\varrho$ should be considered as providing a wide "confidence internal" for empirically plausible values of the elasticity of substitution. ${ }^{27}$ The value of the distribution parameter, $\theta$, is set at 0.25 , so as to ensure that the labour share is close to 60 percent; according to the Ameco database (data accessed on April 22, 2014), the adjusted ${ }^{28}$ wage (i.e. labour) share was on average 58.2\% of GDP for the (12) euro area countries during 1991-2012 when evaluated at market prices, and $65.5 \%$ when evaluated at factor cost.

Parameter $v$, which measures the returns to scale is set at $0.8,{ }^{29}$ implying that the production function is characterized by diminishing returns to scale, thus allowing for positive profits equal to 20 percent of output. These shares are consistent with observed data. For example, according to Eurostat (data accessed on April 22, 2014), for non-financial corporations, net entrepreneurial income (which is gross operating surplus plus all property income received minus interest and rents paid, and which approximates the concept of pre-tax

${ }^{27}$ Our choice of the baseline value for $\sigma$ to be lower than 1 is also influenced by the fact that with the CES production function an elasticity of substitution between capital and labor greater than 1 would imply that production is possible without labor or without capital, which appears - at the current state of technology - implausible (see, e.g. Acemoglu, 2009, p. 519). Despite these reservations, we present also results for the case that $\sigma>1$.

${ }^{28}$ Adjusted for the existence of self-employed persons.

${ }^{29}$ We report also results for $v=0.7$ and $v=0.9$. 
corporate profits in business accounting) as a percentage of net value added, was 32.7 percent on average for the (12) euro area countries during 2002-2012. (During the same period, gross operating surplus was $39 \%$ of gross value added on average for the same group of countries.) The time preference rate, $\beta$, and the capital depreciation rate, $\delta$, are set at 0.98 and 0.08 respectively, which are standard values for these parameters in the literature. In accordance with the relevant empirical studies, we set the baseline value of parameter $a$, which determines the shape of the Pareto distribution and is a measure of income inequality among workers, equal to 2 , and its "extreme" values to 1.5 and $2.5 .{ }^{30}$ Parameter $b$, which stands for the lowest ability in the population of workers, can be chosen arbitrarily so that the model's equilibrium values of the endogenous variables match well with actual economies; we set it to $1 .^{31}$ The baseline value for parameter $\varphi$, which is the ratio of unemployment (or, social welfare) benefits to the minimum wage, is set at 0.35 , but we also provide results for larger values of $\varphi$ (and discuss the implications of smaller values as well). It is clear that the generosity of unemployment benefit schemes differs a lot among countries, and we note that even though the baseline value chosen here may appear on the low side of actual unemployment benefit schemes, remember that in this model the granting of these benefits has an indefinite duration. In this sense, it should be compared more with the social assistance provided to individuals whose eligibility for unemployment benefits has expired, or those who have never fulfilled the eligibility criteria for receiving them.

Finally, we assume that the number of capitalists/entrepreneurs as a share of the total population, $N /(1+N)$, is equal to 0.3 , but we also provide results for the cases that workers comprise either 65 or 75 percent of the population. We report that the substance of our results is robust to changes in the above parameter values.

\subsection{Numerical solution and discussion of results}

Using the baseline parameterization discussed in Table 1, the long-run equilibrium values for the perfectly competitive (PC) and the minimum wage (MW) economies described earlier are presented in Tables 2a-2d. These long-run equilibrium values solutions follow from solving the systems (LR1-LR8) and (LR1a-LR8a, LR9-LR11) respectively.

In Tables $2 \mathrm{a}-2 \mathrm{~d}$ the results are displayed as follows. The PC column represents (for different values of the elasticity of substitution), the long-run values of the perfectly

\footnotetext{
${ }^{30}$ We note that the relationship between parameter $\alpha$ and the Gini coefficient, $G$, is $G=1 /(2 \alpha-1)$, implying that when $\alpha=2, G=0.33$, which is close to observed estimates for income inequality.

${ }^{31}$ This is just a normalization; different values of $b$ would not affect the qualitative nature of the results.
} 
ECONOMIDES, MOUTOS Worker Heterogeneity and Popularity of Minimum Wage

Table 2a: Comparative static results with respect to $\sigma$ in the presence of a linear income $\operatorname{tax}(\tau)$ on all sources of income $(\lambda=0.10)$

\begin{tabular}{|c|c|c|c|c|c|c|}
\hline \multirow[b]{2}{*}{ Variable } & \multicolumn{2}{|c|}{$\sigma=2$} & \multicolumn{2}{|c|}{$\sigma=0.909$} & \multicolumn{2}{|c|}{$\sigma=0.33$} \\
\hline & $\mathrm{PC}$ & MW & PC & MW & $\mathrm{PC}$ & MW \\
\hline$w$ & 0.4788 & - & 0.4853 & - & 0.4870 & - \\
\hline$y$ & - & 0.5267 & - & 0.5339 & - & 0.5357 \\
\hline 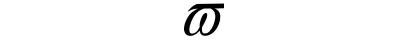 & - & 0.4865 & - & 0.4928 & - & 0.4944 \\
\hline$\varepsilon$ & - & 1.0826 & - & 1.0833 & - & 1.0835 \\
\hline$K$ & 3.5376 & $-7.7 \%$ & 2.1599 & $-7.9 \%$ & 1.6431 & $-7.8 \%$ \\
\hline$L$ & 1.40 & $-7.6 \%$ & 1.40 & $-7.7 \%$ & 1.40 & $-7.7 \%$ \\
\hline$C^{L}($ for $e=b)$ & 0.4788 & - & 0.4853 & - & 0.4870 & - \\
\hline$C^{L}($ for $e=\varepsilon)$ & 0.5184 & $0 \%$ & 0.5257 & $-0.3 \%$ & 0.5277 & $-0.5 \%$ \\
\hline$C^{K}$ & 1.0953 & $-8.0 \%$ & 0.8939 & $-8.0 \%$ & 0.8174 & $-8.0 \%$ \\
\hline$u$ & 0 & $\begin{array}{c}0.1028 \\
(0.1468) \\
\end{array}$ & 0 & $\begin{array}{r}0.1035 \\
(0.1479) \\
\end{array}$ & 0 & $\begin{array}{r}0.1037 \\
(0.1482) \\
\end{array}$ \\
\hline$\tau$ & 0 & 0.0158 & 0 & 0.0184 & 0 & 0.0196 \\
\hline $\begin{array}{l}\% \text { of employed workers } \\
\text { for which } C^{L}{ }_{M W} \geq C^{L}{ }_{P C}\end{array}$ & - & 0.00 & - & 0.00 & - & 0.00 \\
\hline$L I$ & 2.2345 & $-5.0 \%$ & 2.2649 & $-5.1 \%$ & 2.2725 & $-5.3 \%$ \\
\hline Post-tax and -transfers $L S$ & 0.5229 & $1.4 \%$ & 0.6064 & $1.2 \%$ & 0.6441 & $1.0 \%$ \\
\hline
\end{tabular}

Notes to tables 2a-2d: Numbers in bold imply exogenously set policy variables. Also, the MW columns present the equilibrium values of the various variables or, wherever applicable, their percentage changes from the PC case.

competitive, full-employment case, whereas the MW columns represent the outcomes if a minimum wage (per unit of time) is imposed which is arbitrarily or institutionally set higher than the wage (per unit.in the PC case; i.e. $y=(1+\lambda)(b w)=(1+\lambda) w, \lambda>0 .{ }^{32}$ More specifically, the MW columns in Tables $2 \mathrm{a}-2 \mathrm{~d}$ present the equilibrium values of the various variables or, wherever applicable, their percentage changes from the PC case. We focus on the case that $\lambda=0.10$, but we also discuss results from the imposition of a minimum wage which is $30 \%$ higher $(\lambda=0.30)$ than the wage which the worker with the lowest ability would receive in the PC case. In these Tables the parameter describing the generosity of the

${ }^{32}$ In principle, instead of simply setting this exogenous rule for the determination of the minimum wage, we could, as one referee suggested, postulate a social welfare function and derive the "optimal" minimum wage. Nevertheless, any results derived in such a case would depend strongly on the type and parameterization of the social welfare function, e.g. one which gives progressively lower weight to higher income individuals (Atkinson, 1970; Sen, 1977). Moreover, this would require that the government knows the ability of each individual - an assumption which the optimal taxation literature has not been willing to entertain since Mirrlees (1971). 
unemployment benefit system is arbitrarily set at $\phi=0.35$ - the reasons for setting unemployment benefits at $35 \%$ of the minimum wage will become apparent shortly.

The imposition of a minimum wage in an otherwise perfectly competitive economy implies a cost in terms of aggregate (and, per-capita) output and consumption in the long run. (For brevity, we do not report the results for these variables; we report, however, the outcomes for the amounts of capital and labour employed in the economy.) This arises since with a binding minimum wage (per unit of time) firms will not be willing to employ the lowest ability workers, but only those whose ability times the market-determined wage rate, $\varpi$, is larger than the institutionally set minimum wage. The resulting exclusion from employment of some low-ability workers decreases the aggregate units of effective labour employed, increases, at the initial capital stock, the marginal product of (effective) labour, and the wage rate, $\varpi$, per effective unit of labour. These developments lead to a lower capital stock in the long run, which, in combination, with the smaller labour input lead to lower aggregate output, and a lower level of aggregate profits.

In Table 2a, when the elasticity of substitution is equal to 0.909 ( $\varrho=-0.1$ ), the wage rate (per effective unit of labour) in the PC case is $w=0.4853$, thus we set the minimum wage (per unit of time) at $y=(1+\lambda) w=1.1 w=0.5339$. As a result, the firms will not be willing to employ the low-ability workers, and the unemployment rate (expressed as a share of the total population) will rise to $u=10.35 \%$. These developments are associated with a rise in the wage rate to $\varpi=0.4928$, i.e. a rise in the wage rate relative to the PC case by $1.55 \%$. The significantly smaller percentage rise in the wage rate than the $10 \%$ minimumwage premium over the competitive wage (per unit of time) is mostly due to the reduction in the steady-state capital stock $^{33}$ under the MW regime brought about by the reduced incentives for capital accumulation generated by the higher cost of labour and the taxes needed to support the unemployed. As a result, all workers remaining in employment become worse-off, since their (after-tax) income and consumption decrease relative to the PC case; e.g. when $\sigma=0.909$, the consumption of the worker whose ability is equal to the threshold ability level $(\varepsilon=1.0833$ ) decreases from 0.5257 in the PC case to 0.5241 in the MW case (a drop of $0.3 \%$ ). (Since the tax rate is linear in income (and ability), the percentage decline in after-tax income is the same for all workers remaining in employment.) The corresponding decrease in the consumption of all workers below the threshold level of ability - i.e. those that become unemployed after the imposition of the MW - is very large; the consumption of the lowest ability worker $(e=b=1)$ drops from 0.4853 in the PC case to $0.1869(=\phi y)$ in the MW case - a reduction by $61.5 \% .{ }^{34}$ As expected, capitalists are also harmed by the imposition of

\footnotetext{
${ }^{33}$ The reduction in the capital stock is equal to $7.6 \%$ relative to the PC case.

${ }^{34}$ The decline is even larger for the workers who have ability levels $e \in[b, \varepsilon)$.
} 


\section{ECONOMIDES, MOUTOS Worker Heterogeneity and Popularity of Minimum Wage}

the minimum wage - their consumption in the long-run drops by $8.0 \%$ relative to the PC case. Thus, the imposition of a "moderately binding" 35 minimum wage $(\lambda=0.10)$, when combined with "moderate" support for the unemployed $(\phi=0.35)$, generates decreases in income and consumption of all groups (employed and unemployed workers, and capitalists) in the economy.

Table 2a reveals that similar reductions in (employed and unemployed) workers' and capitalists' incomes obtain in the long run due to the imposition of a minimum wage if we assume a smaller elasticity of substitution between labour and capital, e.g. when $\sigma=0.33$. But what if $\sigma$ is significantly higher? Table 2 a reveals that if $\sigma=2$, the imposition of the minimum wage will not reduce the after-tax incomes and consumption of employed workers - although it would still induce large reductions in the consumption of capitalists and of the low-ability workers who lose their jobs. Although we do not report it here, we have verified that if the elasticity of substitution is higher than 2 , it would be possible to increase the consumption of employed workers. This is understandable since a high elasticity of substitution makes the reduction in the effective units of labour at the capitalists' disposal easier to deal with via an increase in the (relative) use of capital, thus inducing a smaller reduction in the capital stock than otherwise. ${ }^{36}$ Nevertheless, since the weight of the empirical evidence indicates that the elasticity of substitution is smaller than 1 - let alone 2 , in what follows we shall concentrate on deriving implications of our analysis by regarding 2 as the upper bound for the value of the elasticity of factor substitution.

It would be wrong to conclude from Table $2 \mathrm{a}$ that the imposition of a minimum wage cannot increase the (after-tax incomes and) consumption of employed workers, since their values depend on assuming that unemployed workers receive welfare benefits equal to $35 \%$ of the minimum wage, i.e. the benefit replacement ratio, $\phi$, is 0.35 . Given the rest of the parameter values, $\phi=0.35$ provides an approximate ${ }^{37}$ threshold above which even the employed workers become worse-off under the MW regime; similarly, if very little support

${ }^{35}$ It is not clear how big is the difference between existing minimum wages (per unit of time) and the hypothetical wage (per unit of time) that the lowest ability worker would earn in a perfectly competitive market. For one thing, no actual labour market can be considered as perfectly competitive even in the absence of a national minimum wage. Nevertheless, a rough approximation may be available if one looks at the German (non-union) low-wage sector. For example, Bosch and Kalina (2008) report that in 2006, 1.9 million workers (about 6.5\% of the workforce) were earning less than $€ 5$ per hour; press reports indicate that some workers were earning substantially less than that $\quad-\quad$ see, e.g. http://www.reuters.com/article/2012/02/08/us-germany-jobsidUSTRE8170P120120208). Given the small increases in wages in Germany since 2006, the $€ 8.5$ per hour minimum wage will certainly be far larger than the $10 \%$ and $30 \%$ premium on the lowest-ability workers assumed here, and for this reason we put the adjective moderate on the $10 \%$ premium.

${ }^{36}$ The percentage reduction in capitalists' consumption is smaller as well in this case.

${ }^{37}$ It is an "approximate" threshold since changes in the rest of the parameter values produce small changes to it. 
was provided for the unemployed $(\phi<0.20)$, then we have verified that under any set of plausible parameter values the employed workers would become better-off if a moderately binding minimum wage was set like the one whose effects are presented in Table 2a; however, the unemployed and the capitalists would still lose from it.

Before we move away from the case of a comprehensive linear tax, we point the reader's attention to Tables $2 b-2 d$. Table $2 b$ differs from Table $2 a$ in only one dimension. It displays the effects of a "heavily binding" minimum wage, i.e. one that sets the minimum wage (per unit of time) at $30 \%$ above $(\lambda=0.30)$ what the lowest-ability worker would earn under competitive conditions (per unit of time). This Table reveals that such a policy would be even more self-defeating (relative to Table 2a) for the (relatively) high-ability workers that remain employed; their (after-tax) income and consumption would drop relative to the PC case since (i) they would have to shoulder a heavier tax burden in order to finance the welfare benefits for the significantly higher number of unemployed and (ii) the capitalists' (further) reduced incentives for capital accumulation would lead to greater declines in the capital stock and the demand for labour. This implies that under a "heavily binding" minimum wage the employed workers can be made better-off only if the support provided to the unemployed is very

Table 2b:Comparative static results with respect to $\sigma$ in the presence of a linear income $\operatorname{tax}(\tau)$ on all sources of income $(\lambda=0.30)$

\begin{tabular}{|c|c|c|c|c|c|c|}
\hline \multirow[b]{2}{*}{ Variable } & \multicolumn{2}{|c|}{$\sigma=2$} & \multicolumn{2}{|c|}{$\sigma=0.909$} & \multicolumn{2}{|c|}{$\sigma=0.33$} \\
\hline & PC & MW & $\mathrm{PC}$ & MW & $\mathrm{PC}$ & MW \\
\hline$w$ & 0.4788 & - & 0.4853 & - & 0.4870 & - \\
\hline$y$ & - & 0.6224 & - & 0.6309 & - & 0.6331 \\
\hline $\bar{\sigma}$ & - & 0.4993 & - & 0.5053 & - & 0.5068 \\
\hline$\varepsilon$ & - & 1.2465 & - & 1.2486 & - & 1.2492 \\
\hline$K$ & 3.5376 & $-21.3 \%$ & 2.1599 & $-21.41 \%$ & 1.6431 & $-20.61 \%$ \\
\hline$L$ & 1.40 & $-19.7 \%$ & 1.40 & $-19.9 \%$ & 1.40 & $-20.0 \%$ \\
\hline$C^{L}($ for $e=b)$ & 0.4788 & $-54.5 \%$ & 0.4853 & $-54.5 \%$ & 0.4870 & $-54.5 \%$ \\
\hline$C^{L}($ for $e=\varepsilon)$ & 0.5968 & $-1.0 \%$ & 0.6060 & $-2.0 \%$ & 0.6084 & $-2.5 \%$ \\
\hline$C^{K}$ & 1.0953 & $-20.9 \%$ & 0.8939 & $-21.51 \%$ & 0.8174 & $-21.54 \%$ \\
\hline$u$ & 0 & $\begin{array}{c}0.2494 \\
(0.3564) \\
\end{array}$ & 0 & $\begin{array}{c}0.2510 \\
(0.3586) \\
\end{array}$ & 0 & $\begin{array}{c}0.2515 \\
(0.3592) \\
\end{array}$ \\
\hline$\tau$ & 0 & 0.0508 & 0 & 0.0593 & 0 & 0.0630 \\
\hline $\begin{array}{l}\text { \% of employed workers } \\
\text { for which } C^{L}{ }_{M W} \geq C_{P C}^{L}\end{array}$ & - & 0.00 & - & 0.00 & - & 0.00 \\
\hline$L I$ & 2.2345 & $-12.5 \%$ & 2.2649 & $-13.40 \%$ & 2.2725 & $-13.76 \%$ \\
\hline Post-tax and -transfers $L S$ & 0.5229 & $4.9 \%$ & 0.6064 & $3.8 \%$ & 0.6441 & $3.2 \%$ \\
\hline
\end{tabular}

Notes: Numbers in bold imply exogenously set policy variables. Also, the MW columns present the equilibrium values of the various variables or, wherever applicable, their percentage changes from the PC case. 


\section{ECONOMIDES, MOUTOS Worker Heterogeneity and Popularity of Minimum Wage}

limited - our numerical results suggest that $\phi<0.10$ is a necessary condition for such an outcome.

Table $2 \mathrm{~d}$ presents the effects from varying the assumed percentage of capitalists in the population, and it shows that these variations do not alter the broad picture established by the previous Tables. Further experimentation with variations in other assumed parameter values (e.g. the share of profits in aggregate income) has verified that under a comprehensive linear tax the imposition of a binding minimum wage can increase the (after-tax) income of those remaining in employment but only if the support provided to the unemployed is far below what they could earn under a PC regime.

In summary, our findings indicate that the presence of worker heterogeneity and the existence of another distinct social class (i.e. capitalists) are crucial for the creation of a political majority for the MW institution. Worker heterogeneity is important since in its absence the fall in the expected wage income of all workers (as the probability of unemployment would be the same for all workers) would have all workers be against any unemployment-creating minimum inefficiency introduced by the minimum wage would harm the workers as there would be no other group on which the cost of inefficiency can be

Table 2c: Comparative static results with respect to $\alpha$ in the presence of a linear income tax $(\tau)$ on all sources of income $(\lambda=0.10)$

\begin{tabular}{|c||c|c|c|c|c|c|}
\hline \multirow{2}{*}{\multicolumn{1}{|c||}{ Variable }} & \multicolumn{2}{c|}{$\alpha=1.5$} & \multicolumn{2}{c|}{$\alpha=2.0$} & \multicolumn{2}{c|}{$\alpha=2.5$} \\
\cline { 2 - 7 } & PC & MW & PC & MW & PC & MW \\
\hline \hline$w$ & 0.4386 & - & 0.4853 & - & 0.5079 & - \\
\hline$y$ & - & $\mathbf{0 . 4 8 2 5}$ & - & $\mathbf{0 . 5 3 3 9}$ & - & $\mathbf{0 . 5 5 8 7}$ \\
\hline$\sigma$ & - & 0.4423 & - & 0.4928 & - & 0.5188 \\
\hline$\varepsilon$ & - & 1.0908 & - & 1.0833 & - & 1.0769 \\
\hline$K$ & 2.9552 & $-4.3 \%$ & 2.1599 & $-7.9 \%$ & 1.8759 & $-10.9 \%$ \\
\hline$L$ & 2.10 & $-4.25 \%$ & 1.40 & $-7.7 \%$ & 1.1667 & $-10.5 \%$ \\
\hline$C^{L}($ for $e=b)$ & 0.4386 & $-61.5 \%$ & 0.4853 & $-61.48 \%$ & 0.5079 & $-61.5 \%$ \\
\hline$C^{L}($ for $e=\varepsilon)$ & 0.4784 & $-0.1 \%$ & 0.5257 & $-0.3 \%$ & 0.5470 & $-0.5 \%$ \\
\hline$C^{K}$ & 1.2159 & $-4.4 \%$ & 0.8939 & $-8.0 \%$ & 0.7784 & $-10.95 \%$ \\
\hline$u$ & 0 & 0.0856 & 0 & 0.1035 & 0 & 0.1184 \\
\hline$\tau$ & 0 & 0.0098 & 0 & 0.0184 & 0 & 0.0259 \\
\hline \% of employed workers for & & & & & & \\
\hline$L I$ & 3.0703 & $-2.82 \%$ & 2.2649 & $-5.13 \%$ & 1.9751 & $-7.06 \%$ \\
\hline Post-tax and -transfers $L S$ & 0.6051 & $0.62 \%$ & 0.6064 & $1.18 \%$ & 0.6070 & $1.68 \%$ \\
\hline
\end{tabular}

Notes: Numbers in bold imply exogenously set policy variables. Also, the MW columns present the equilibrium values of the various variables or, wherever applicable, their percentage changes from the PC case. 
Table 2d: Comparative static results with respect to $\mathrm{N}^{\mathrm{k}} /\left(\mathrm{N}^{\mathrm{k}}+\mathrm{N}^{\mathrm{L}}\right)$ in the presence of a linear income tax $(\tau)$ on all sources of income $(\lambda=0.10)$

\begin{tabular}{|c|c|c|c|c|c|c|}
\hline \multirow[b]{2}{*}{ Variable } & \multicolumn{2}{|c|}{$N^{k} /\left(N^{k}+N^{L}\right)=0.25$} & \multicolumn{2}{|c|}{$N^{k} /\left(N^{k}+N^{L}\right)=0.30$} & \multicolumn{2}{|c|}{$N^{k} /\left(N^{k}+N^{L}\right)=0.35$} \\
\hline & $\mathrm{PC}$ & MW & $\mathrm{PC}$ & MW & $\mathrm{PC}$ & MW \\
\hline$w$ & 0.4558 & - & 0.4853 & - & 0.5137 & - \\
\hline$y$ & - & 0.5014 & - & 0.5339 & - & 0.5651 \\
\hline $\bar{\sigma}$ & - & 0.4629 & - & 0.4928 & - & 0.5217 \\
\hline$\varepsilon$ & - & 1.0832 & - & 1.0833 & - & 1.0832 \\
\hline$K$ & 2.1860 & $-8.0 \%$ & 2.1599 & $-8.0 \%$ & 2.1121 & $-8.0 \%$ \\
\hline$L$ & 1.50 & $-7.70 \%$ & 1.40 & $-7.70 \%$ & 1.30 & $-7.70 \%$ \\
\hline$C^{L}($ for $e=b)$ & 0.4558 & $-61.5 \%$ & 0.4853 & $-61.5 \%$ & 0.5137 & $-61.5 \%$ \\
\hline$C^{L}($ for $e=\varepsilon)$ & 0.4937 & $-0.3 \%$ & 0.5257 & $-0.3 \%$ & 0.5564 & $-0.3 \%$ \\
\hline$C^{K}$ & 1.0817 & $-8.0 \%$ & 0.8939 & $-8.0 \%$ & 0.7517 & $-8.0 \%$ \\
\hline$u$ & 0 & $\begin{array}{l}0.1108 \\
(0.1477)\end{array}$ & 0 & $\begin{array}{c}0.1035 \\
(0.1479)\end{array}$ & 0 & $\begin{array}{c}0.0960 \\
(0.1477)\end{array}$ \\
\hline$\tau$ & 0 & 0.0184 & 0 & 0.0184 & 0 & 0.0184 \\
\hline $\begin{array}{l}\% \text { of employed workers } \\
\text { for which } C^{L}{ }_{M W} \geq C_{P C}^{L}\end{array}$ & - & 0.00 & - & 0.00 & - & 0.00 \\
\hline$L I$ & 2.7350 & $-5.13 \%$ & 2.2649 & $-5.13 \%$ & 1.9082 & $-5.13 \%$ \\
\hline Post-tax and -transfers $L S$ & 0.6056 & $1.18 \%$ & 0.6064 & $1.18 \%$ & 0.6072 & $1.18 \%$ \\
\hline
\end{tabular}

Notes: Numbers in bold imply exogenously set policy variables. Also, the MW columns present the equilibrium values of the various variables or, wherever applicable, their percentage changes from the PC case.

transferred to and from which workers extract a larger share of output. The above also imply that the specific functional form used for the production function is not essential for our results.

\section{Non-Linear Taxes}

Actual tax systems are not characterized by the existence of a single, linear tax rate on all sources of income. We thus enquire in this section to what extent our previous conclusions should be modified once we allow for tax progressivity and greater flexibility in extracting taxes for the funding of welfare support to the unemployed.

\subsection{Progressive Taxes}

We introduce progressive taxation in the model in a very simple way. That is, we impose a single tax rate on all sources of income, but for labour income alone, any income below a threshold level, $z$, goes untaxed. We continue assuming that unemployment benefits are untaxed, and - for simplicity -we set $z$ equal to what the lowest ability worker would receive 


\section{ECONOMIDES, MOUTOS Worker Heterogeneity and Popularity of Minimum Wage}

in the PC case, i.e. $z=b w$. As a result, equations (LR1a) and (LR11) - which correspond to the consumption of workers and the government budget constraint - should be modified to:

$$
\begin{gathered}
C_{i}^{L}=e_{i} \varpi-\tau\left(e_{i} \varpi-b w\right) \\
\phi y u=\tau(Y-(1-u) b w)
\end{gathered}
$$

The right-hand-side of equation (LR11a) represents tax revenue. These are equal to the (single) tax rate times the part of aggregate income which is subject to taxation. The latter is equal to aggregate income, $Y$, minus the aggregate labour income which is not subject to taxation (which is equal to the number of employed workers $(1-u)$ times the untaxed level of labour income $(b w))$.

Table 3a displays the steady-state outcomes for the PC and MW regimes under the modified tax structure for $\lambda=0.10$. Whereas in Table $2 \mathrm{a}$ values of the benefit replacement ratio $(\phi)$ as low as 0.35 resulted in no employed workers being made better-off under the MW regime, in Table $3 \mathrm{a}$ as many as $89 \%$ of the employed workers (when $\sigma=2$ ) could be made better-off from the introduction of the MW; the proportion of employed workers which become better-off declines to $74 \%$, when $\sigma=0.9$, and to $67 \%$ when $\sigma=0.33$. The employed workers which become better-off are the ones whose ability is not too-high, i.e. the ones that (due to the tax exemption) would face a smaller increase in their tax burden than the rise in the wage rate, $\varpi$, which the MW regime would generate. By analogy, the high-ability workers - as well as the capitalists - would have to shoulder a larger part of the tax burden, and their after-tax incomes would decline. ${ }^{38}$

This is an instance in which minimum wages cause a two-sided redistribution even among workers - in the sense that the MW regime can reduce the after-tax incomes of both (very) low-ability and (very) high-ability workers. This can, in turn, reduce the political feasibility of minimum wages if they are combined with substantial welfare support for the unemployed. For example, Table 3a reveals that if $\phi=0.5$, only $40 \%$ of employed workers would benefit from the MW regime if $\sigma=0.9$. This implies that if voters cared only about their own aftertax incomes, there would be a strong majority in the population against the MW regime; this majority would consist of the $60 \%$ of employed workers, and the entirety of capitalists $(30 \%$ of voters) and of the unemployed workers. Such outcomes can potentially explain differences in attitudes between Scandinavian and Southern European countries; a well-developed social

\footnotetext{
${ }^{38}$ The reader can verify that the percentage decline in the consumption of capitalists due to the MW regime is larger in Table $3 a$ than the corresponding case in Table 2a.
} 
Review of Economic Analysis 1 (2019) 1-38

Table 3a: Comparative static results with respect to $\sigma$ in the presence of non-linear taxes

$$
(\lambda=0.10)
$$

\begin{tabular}{|c|c|c|c|c|c|c|c|c|c|c|c|c|}
\hline \multirow[b]{3}{*}{ Variable } & \multicolumn{4}{|c|}{$\sigma=2$} & \multicolumn{4}{|c|}{$\sigma=0.9$} & \multicolumn{4}{|c|}{$\sigma=0.33$} \\
\hline & \multirow{2}{*}{ PC } & \multicolumn{3}{|c|}{ MW } & \multirow{2}{*}{$\mathrm{PC}$} & \multicolumn{3}{|c|}{ MW } & \multirow[t]{2}{*}{$\mathrm{PC}$} & \multicolumn{3}{|c|}{ MW } \\
\hline & & $\varphi=0.35$ & $\varphi=0.5$ & $\varphi=0.909$ & & $\varphi=0.35$ & $\varphi=0.5$ & $\varphi=0.909$ & & $\begin{array}{c}\varphi=0.3 \\
5\end{array}$ & $\varphi=0.5$ & $\begin{array}{l}\varphi=0.90 \\
9\end{array}$ \\
\hline$w$ & 0.4788 & - & - & - & 0.4853 & 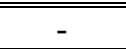 & - & - & 0.4870 & - & 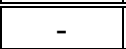 & - \\
\hline$y$ & - & 0.5267 & 0.5267 & 0.5267 & - & 0.5339 & 0.5339 & 0.5339 & - & 0.5357 & \begin{tabular}{|l|}
0.5357 \\
\end{tabular} & 0.5357 \\
\hline$\Phi$ & - & 0.4859 & 0.4849 & 0.4817 & - & 0.4921 & 0.4909 & 0.4869 & - & 0.4936 & \begin{tabular}{|l|}
0.4924 \\
\end{tabular} & 0.4884 \\
\hline$\varepsilon$ & - & 1.0839 & 1.0862 & 1.0935 & - & 1.0850 & 1.0877 & 1.0966 & - & 1.0852 & \begin{tabular}{|l|}
1.0879 \\
\end{tabular} & 1.0968 \\
\hline$K$ & 3.5376 & $-8.9 \%$ & $-11.4 \%$ & $-18.7 \%$ & 2.1599 & $-8.9 \%$ & $-10.3 \%$ & $-14.9 \%$ & 1.6431 & $-8.3 \%$ & $-9.0 \%$ & $-11.3 \%$ \\
\hline$L$ & 1.40 & $-7.7 \%$ & $-7.9 \%$ & $-8.6 \%$ & 1.40 & $-7.8 \%$ & $-8.1 \%$ & $-8.8 \%$ & 1.40 & $-7.9 \%$ & $-8.1 \%$ & $-8.8 \%$ \\
\hline$C^{L}($ for $e=b)$ & 0.4788 & $-61.5 \%$ & $-45.0 \%$ & $0.0 \%$ & 0.4853 & $-61.5 \%$ & $-45.0 \%$ & $0.0 \%$ & 0.4870 & $61.5 \%$ & \begin{tabular}{|c|}
- \\
$45.0 \%$ \\
\end{tabular} & $0.0 \%$ \\
\hline $\begin{array}{c}C^{L}{ }_{P C}(\text { for } e=\varepsilon) \\
\mathrm{C}^{\mathrm{L}}{ }_{\mathrm{MW}}(\text { for } e=\varepsilon)\end{array}$ & & $\begin{array}{l}0.519 \\
1.3 \%\end{array}$ & $\begin{array}{c}0.5201 \\
1.0 \%\end{array}$ & $\begin{array}{c}0.5235 \\
0.0 \%\end{array}$ & & $\begin{array}{c}0.5265 \\
1.2 \%\end{array}$ & $\begin{array}{c}0.5279 \\
0.8 \%\end{array}$ & $\begin{array}{l}0.5322 \\
-0.4 \%\end{array}$ & & $\begin{array}{c}0.5285 \\
1.1 \%\end{array}$ & $\begin{array}{c}0.5298 \\
0.7 \%\end{array}$ & $\begin{array}{l}0.5341 \\
-0.4 \%\end{array}$ \\
\hline$C^{K}$ & 1.0953 & $-8.6 \%$ & $-10.4 \%$ & $-16.2 \%$ & 0.8939 & $-8.9 \%$ & $-10.5 \%$ & $-15.3 \%$ & 0.8174 & $-9.2 \%$ & \begin{tabular}{|c|}
- \\
$10.3 \%$ \\
\end{tabular} & $-14.7 \%$ \\
\hline$u$ & 0 & $\begin{array}{l}0.1041 \\
(0.148)\end{array}$ & $\begin{array}{l}0.1067 \\
(0.152)\end{array}$ & $\begin{array}{l}0.1146 \\
(0.163)\end{array}$ & 0 & $\begin{array}{l}0.1053 \\
(0.150)\end{array}$ & $\begin{array}{l}0.1083 \\
(0.154)\end{array}$ & $\begin{array}{l}0.1179 \\
(0.168)\end{array}$ & 0 & $\begin{array}{c}0.1056 \\
(0.150 \\
)\end{array}$ & \begin{tabular}{|c|}
0.1086 \\
$(0.155$ \\
)
\end{tabular} & $\begin{array}{l}0.1181 \\
(0.168)\end{array}$ \\
\hline$\tau$ & 0 & 0.0210 & 0.0311 & 0.0627 & 0 & 0.0259 & 0.0383 & 0.0769 & 0 & 0.0282 & 0.0416 & 0.0827 \\
\hline $\begin{array}{c}\% \text { of employed } \\
\text { workers for } \\
\text { which } C^{L}{ }_{M W} \geq \\
C^{L}{ }_{P C}\end{array}$ & - & 89.21 & 57.19 & 0.81 & - & 73.81 & 40.07 & 0.00 & - & 67.03 & 35.06 & 0.00 \\
\hline$L I$ & 2.2345 & $-4.5 \%$ & $-4.2 \%$ & $-3.0 \%$ & 2.2649 & $-5.0 \%$ & $-4.7 \%$ & $-3.9 \%$ & 2.2725 & $-5.1 \%$ & $-4.9 \%$ & $-4.2 \%$ \\
\hline $\begin{array}{l}\text { Post-tax and - } \\
\text { transfers } L S\end{array}$ & 0.5229 & $2.1 \%$ & $3.5 \%$ & $7.6 \%$ & 0.6064 & $1.7 \%$ & $2.4 \%$ & $4.8 \%$ & 0.6441 & $1.4 \%$ & $1.9 \%$ & $3.6 \%$ \\
\hline
\end{tabular}

Notes: Numbers in bold imply exogenously set policy variables. Also, the MW columns present the equilibrium values of the various variables or, wherever applicable, their percentage changes from the PC case.

safety net in Scandinavia tends to co-exist with the absence of a national minimum wage, whereas in Southern Europe nationally binding (and relatively-high) national minimum wages are usually paired with the absence of a well-developed social safety net. ${ }^{39}$

${ }^{39}$ For example, currently in Greece the unemployment rate is close to $20 \%$ and yet only one in ten of the unemployed receive unemployment benefits; this is due to various strict eligibility criteria. Moreover, the monthly unemployment benefit is set at $€ 360$ (which is $55 \%$ of the minimum wage), is independent of previous earnings, and its maximum duration is 12 months; for those ineligible to receive unemployment benefits there exist some welfare benefits whose maximum monthly value (if eligibility criteria make it available) is $€ 200$. 


\section{ECONOMIDES, MOUTOS Worker Heterogeneity and Popularity of Minimum Wage}

Arguably, it can also explain the US case as well. ${ }^{40}$

The (apparent) political infeasibility of the MW regime when combined with generous welfare support for the unemployed -under the assumption that voters consider the present model as the true description of their environment - is in large part due to the reduction in the capital stock that the increase in taxation engenders. What if political reality allowed for different tax rates across income sources? This is the issue we now turn to.

\subsection{Exempting Capital Income from Taxation}

In addition to the having a part, $z(=b w)$, of labour income which is exempt from taxation, we now assume that all capital income $(=r K)$ is also exempt from taxation. Moreover, we assume that political reality allows the burden of taxation to be split according to the following ad-hoc rule:

$$
\tau^{L}=\gamma \tau^{K},>0
$$

where $\tau^{L}$ and $\tau^{K}$ stand for the tax rates on wages and on profits (respectively). This (ad-hoc) rule is introduced here in order to allow for a simple way of apportioning the burden of taxation that the MW generates. ${ }^{41}$ It also it implies that both $\tau^{L}$ and $\tau^{K}$ adjust endogenously so as to keep the government's budget in balance -i.e. the model now admits one more endogenous variable and it involves one extra equation (equation 22). As a result, in the MW regime, the equations corresponding to the consumption of workers, capitalists and the government budget constraint are now modified to:

$$
C_{i}^{L}=e_{i} \varpi-\tau^{L}\left(e_{i} \varpi-b w\right)
$$

\footnotetext{
${ }^{40}$ This raises an important question: why have some countries developed generous and efficient social welfare systems while eschewing the nationally determined minimum wage institution, whereas other countries relied on the latter as a way to address the lack of an adequate social safety net? Aghion et al. (2011) argue that the quality of labour relations in a country (as evidenced in the level of trust in labour relationships and the degree of unionization) may be inversely related to the state's regulation of the minimum wage institution, with the causality running both ways: on the one hand, stringent minimum wage regulations discourage social investments in labor relations; on the other hand, low investments in labor relations induce democratic governments to introduce minimum wage policies to protect the median voter. We may think that a similar two-way causality is involved in the present paper: on the one hand, a generous social welfare state shuns minimum wage legislation since the financial cost of the unemployment generated by the minimum wage is high; on the other hand, the existence of a minimum wage (especially of a high one) prevents - by making it very costly - the emergence of a an adequate social safety net.

${ }^{41}$ It would be straightforward to allow for a non-zero tax rate on capital income which differs from the other tax rates by imposing another similar rule.
} 
Review of Economic Analysis 1 (2019) 1-38

$$
\begin{gathered}
1=\beta(r+1-\delta) \\
C^{K}+\delta K=\left(1-\tau^{K}\right) \Pi+r K \\
\phi y u=\tau^{L}\left[\frac{\alpha}{\alpha-1}\left\{\frac{b}{\epsilon}\right\}^{\alpha} \varpi-(1-u) b w\right]+\tau^{K} \Pi .
\end{gathered}
$$

Equation (LR11b) just states that the value of unemployment benefit payments must equal the government's total tax receipts. The receipts equal the sum of the profit-tax revenue $\left(\tau^{K} \Pi\right)$, and the taxes raised on labour income; the latter are equal to the total income of employed workers (i.e. the total effective units of labour employed times the wage rate $\left(=\frac{\alpha}{\alpha-1}\left\{\frac{b}{\epsilon}\right\}^{\alpha} \varpi\right)$ minus the total income of employed workers which is exempt from taxation $(=(1-u) b w))$ times the tax rate on wage income.

Table $3 \mathrm{~b}$ displays the comparison between the PC and MW regimes in the case that $\gamma=0.20$, and for $\lambda=0.10$. The reduced tax burden which employed workers now face, allows for all employed workers to be better-off under the MW regime - independently of the value of the elasticity of substitution - even when the welfare support provided to the unemployed is fairly generous, i.e. $\phi=0.50$. This implies a majority in favour of the MW regime. We note that the MW regime could still be supported by a majority even if welfare support to the unemployed is very generous, i.e. $\phi=0.80$, since when $\sigma=0.9$ (or $\sigma=2$ ) there would still be $86 \%$ (or $92 \%$ ) among the employed workers who would be better off with the MW regime. If the elasticity of substitution is small $(\sigma=0.33)$, only $82 \%$ among the employed workers would be in favour of the MW regime, thus, if only income mattered for voting decisions, the capitalists ( $30 \%$ of voters), the $18 \%$ of employed workers losing from the MW (about $11 \%$ of voters), and the unemployed (about $10 \%$ of voters) could form a narrow majority against the MW regime.

Naturally, such a transfer of the tax burden toward the capitalists would result in a far higher reduction in their after-tax income and consumption (relative to the PC case) than when there is a common tax rate on wage and profit income (Table 3a). As a result, the change in the post-tax and-transfers share of aggregate income appropriated by workers, LS, would be substantial; i.e. the MW regime would increase it by 3 percentage points (from $60.6 \%$ to $63.6 \%$ ) relative to the PC case even when the elasticity of substitution between capital and labour is close to $1(\sigma=0.9)$. The concomitant increase in political power by the workers to shape future policy would be enhanced considerably.

Before discussing further, the possible political economy ramifications, we note that the results remain substantially unaltered as the proportion of capitalists in the population changes (Table 3c) or in the shape of the ability distribution (not reported). Nevertheless, it is worth reporting the effects of imposing a heavily-binding minimum wage $(\lambda=0.30)$ under 


\section{ECONOMIDES, MOUTOS Worker Heterogeneity and Popularity of Minimum Wage}

Table $3 \mathrm{~b}$ : Comparative static results with respect to $\sigma$ when capital income is exempt from taxation $(\lambda=0.10, \gamma=0.2)$

\begin{tabular}{|c|c|c|c|c|c|c|c|c|c|c|c|c|}
\hline \multirow{3}{*}{ Variable } & \multicolumn{4}{|c|}{$\sigma=2$} & \multicolumn{4}{|c|}{$\sigma=0.9$} & \multicolumn{4}{|c|}{$\sigma=0.33$} \\
\hline & \multirow{2}{*}{$\mathrm{PC}$} & \multicolumn{3}{|c|}{ MW } & \multirow{2}{*}{$\mathrm{PC}$} & \multicolumn{3}{|c|}{ MW } & \multirow{2}{*}{$\mathrm{PC}$} & \multicolumn{3}{|c|}{ MW } \\
\hline & & $\varphi=0.35$ & $\varphi=0.5$ & $\varphi=0.909$ & & $\varphi=0.35$ & $\varphi=0.5$ & $\varphi=0.909$ & & $\varphi=0.35$ & $\varphi=0.5$ & $\varphi=0.909$ \\
\hline$w$ & 0.4788 & - & - & - & 0.4853 & - & - & - & 0.4870 & - & - & - \\
\hline$y$ & - & 0.5267 & 0.5267 & 0.5267 & - & 0.5339 & 0.5339 & 0.5339 & - & $\mathbf{0 . 5 3 5 7}$ & 0.5357 & 0.5357 \\
\hline $\bar{\sigma}$ & - & 0.4881 & 0.4881 & 0.4881 & - & 0.4947 & 0.4947 & 0.4947 & - & 0.4962 & 0.4962 & 0.4962 \\
\hline$\varepsilon$ & - & 1.0790 & 1.0790 & 1.0790 & - & 1.0793 & 1.0793 & 1.0793 & - & 1.0797 & 1.0797 & 1.0797 \\
\hline$K$ & 3.5376 & $-3.7 \%$ & $-3.7 \%$ & $-3.7 \%$ & 2.1599 & $-5.7 \%$ & $-5.7 \%$ & $-5.7 \%$ & 1.6431 & $-6.8 \%$ & $-6.8 \%$ & $-6.8 \%$ \\
\hline$L$ & 1.40 & $-7.3 \%$ & $-7.3 \%$ & $-7.3 \%$ & 1.40 & $-7.4 \%$ & $-7.4 \%$ & $-7.4 \%$ & 1.40 & $-7.4 \%$ & $-7.4 \%$ & $-7.4 \%$ \\
\hline$C^{L}($ for $e=b)$ & 0.4788 & $-61.5 \%$ & $-45.0 \%$ & $0.0 \%$ & \begin{tabular}{|l|}
0.4853 \\
\end{tabular} & $-61.5 \%$ & $-45.0 \%$ & $0.0 \%$ & 0.4870 & $-61.5 \%$ & $-45.0 \%$ & $0.0 \%$ \\
\hline$C^{L}($ for $e=\varepsilon)$ & 0.5166 & $1.8 \%$ & $1.8 \%$ & $1.7 \%$ & 0.5238 & $1.8 \%$ & $1.8 \%$ & $1.6 \%$ & 0.5258 & $1.7 \%$ & $1.7 \%$ & $1.5 \%$ \\
\hline$C^{K}$ & 1.0953 & $-8.9 \%$ & $-10.8 \%$ & $-15.8 \%$ & \begin{tabular}{|l|}
0.8939 \\
\end{tabular} & $-10.8 \%$ & $-13.0 \%$ & $-19.1 \%$ & 0.8174 & $-11.6 \%$ & $-14.0 \%$ & $-20.6 \%$ \\
\hline$u$ & 0 & $\begin{array}{l}0.0988 \\
(0.141) \\
\end{array}$ & $\begin{array}{r}0.0988 \\
(0.141) \\
\end{array}$ & $\begin{array}{c}0.0988 \\
(0.141) \\
\end{array}$ & 0 & $\begin{array}{l}0.0991 \\
(0.142) \\
\end{array}$ & $\begin{array}{l}0.0991 \\
(0.142) \\
\end{array}$ & $\begin{array}{l}0.0991 \\
(0.142) \\
\end{array}$ & 0 & $\begin{array}{l}0.0995 \\
(0.142) \\
\end{array}$ & $\begin{array}{r}0.0995 \\
(0.142) \\
\end{array}$ & $\begin{array}{r}0.0995 \\
(0.142) \\
\end{array}$ \\
\hline$\tau^{L}$ & 0 & 0.0116 & 0.0166 & 0.0302 & 0 & 0.0132 & 0.0188 & 0.0342 & 0 & 0.0138 & 0.0198 & 0.0360 \\
\hline$\tau^{\pi}$ & 0 & 0.0582 & 0.0831 & 0.1511 & 0 & 0.0658 & 0.0940 & 0.1709 & 0 & 0.0692 & 0.0989 & 0.1798 \\
\hline $\begin{array}{l}\text { \% of employed workers } \\
\text { for which } C_{M W}^{L} \geq C^{L}{ }_{P C}\end{array}$ & - & 100.00 & 100.00 & 83.67 & - & 100.00 & 100.00 & 75.62 & - & 100.00 & 99.47 & 71.52 \\
\hline$L I$ & 2.2345 & $-3.4 \%$ & $-2.5 \%$ & $-0.003 \%$ & 2.2649 & $-3.5 \%$ & $-2.6 \%$ & $-0.25 \%$ & 2.2725 & $-3.6 \%$ & $-2.7 \%$ & $-0.4 \%$ \\
\hline $\begin{array}{c}\text { Post tax- and -transfers } \\
L S\end{array}$ & 0.5229 & $1.6 \%$ & $2.5 \%$ & $5.1 \%$ & 0.6064 & $2.2 \%$ & $3.1 \%$ & $5.7 \%$ & 0.6441 & $2.4 \%$ & $3.3 \%$ & $5.8 \%$ \\
\hline
\end{tabular}

Notes: Numbers in bold imply exogenously set policy variables. Also, the MW columns present the equilibrium values of the various variables or, wherever applicable, their percentage changes from the PC case.

the tax structure just discussed. Table $3 \mathrm{~d}$ shows that if the political equilibrium allowed the workers to force the capitalists to accept a very high tax rate on profits, the increase in the $L S$ would be enormous - an increase by 8 percentage points (even when $\sigma=0.90$ ) relative to the PC case. However, this policy would create such high unemployment that it would be impossible to provide even moderate welfare support to the unemployed (e.g. $\phi=0.35$ ) and receive more than $50 \%$ of the popular vote. Moreover, the very large increase in the tax rate on profits which it would imply raises questions about its political feasibility.

For this reason, in Tables 3e and $3 \mathrm{f}$ we depict cases of less "worker-friendly" ways of apportioning the burden of taxation that moderate increases in the MW (for $\lambda=0.10$ ) generate. In Table $3 \mathrm{e}$, we have set $\gamma=0.50$ and observe that only if welfare support to the unemployed is moderate $(\phi=0.35)$ can there be a majority in favour of the MW. The higher tax burden that employed workers would have in this case (relative to when $\gamma=0.20$ ), generates a smaller 
proportion among employed workers that are in favour of the MW institution when $\phi=0.50$, thus a majority of voters would be against it (i.e. all capitalists, the top $24 \%$ in terms of ability among the employed, and all the unemployed).

In Table $3 \mathrm{f}$ we have set $\gamma=1$, and so this case is directly comparable to the one in Table $3 \mathrm{a}$; the only difference between the two cases is that capital income is exempt from taxation regarding the results depicted in Table 3f. When the elasticity of substitution is below one $(\sigma=0.9, \sigma=0.33)$, exempting capital income from taxation increases the proportion of employed workers who benefit from the imposition of a MW relative to when capital income is not exempt - for example, if $\phi=0.50$, the proportions are $40 \%$ when capital income is not exempt, and $57 \%$ when it is. However, this increase in the proportion of employed workers is not sufficient to create a majority in favour of the MW. Moreover, the same holds true even if welfare support for the unemployed is limited $(\phi=0.35)$. We note that if $\sigma=2$, then the result is reversed, i.e. the proportion of employed workers that benefit from the MW decreases when capital income is exempt from taxation. This is because when the elasticity of factor substitution is high, the extra capital stock that the exemption of capital income from taxation would generate would not be as important as the further rise in the tax rate that employed workers would have to face if part of the potential tax base goes untaxed. ${ }^{42}$ (Naturally, the income, and consumption, of capitalists would be larger if capital income is exempted from taxation).

In summary, the existence of progressive taxation creates a further cleavage between workers regarding the adoption of a MW regime, i.e. whereas under proportional taxation there is a cleavage between all employed workers and the unemployed, under progressive taxation a coalition may develop between the lowest- and the highest-ability workers who both may lose from the adoption of a MW regime. Nevertheless, the likelihood of a majority in favour of the MW regime that provides at least moderate welfare support to the unemployed increases if a progressive tax structure is in place.

\section{Politico-Economic Considerations}

From a normative perspective - which is not the focus of our analysis - it is not evident that the outcomes described in Sections 3 and 4 would induce a social planner whose objective is the maximization of some social welfare measure to impose a minimum wage. Assuming that social welfare is some (possibly weighted) aggregate of individual utilities, which in turn are functions of individual consumption alone, it is clear that - unless the social welfare function gives very small weight to the utility of the lowest-ability workers (who become unemployed) and to capitalists- social welfare would be lower in the MW regime than in the PC one.

\footnotetext{
${ }^{42}$ Given the rest of the parameter values, this result would obtain for values of $\sigma$ larger than 1.3 , and it can potentially "rationalize" why taxing capital income remains popular despite its avowed detrimental effects on capital accumulation if the elasticity of factor substitution is high.
} 
ECONOMIDES, MOUTOS Worker Heterogeneity and Popularity of Minimum Wage

Table 3c: Comparative static results wrt $\mathrm{N}^{\mathrm{k}} /\left(\mathrm{N}^{\mathrm{k}}+\mathrm{N}^{\mathrm{L}}\right)$ when capital income is exempt from taxation $(\lambda=0.10, \gamma=0.2)$

\begin{tabular}{|c|c|c|c|c|c|c|c|c|c|c|c|c|}
\hline \multirow{3}{*}{ Variable } & \multicolumn{4}{|c|}{$N^{k} /\left(N^{k}+N^{L}\right)=0.25$} & \multicolumn{4}{|c|}{$N^{k} /\left(N^{k}+N^{L}\right)=0.30$} & \multicolumn{4}{|c|}{$N^{k} /\left(N^{k}+N^{L}\right)=0.35$} \\
\hline & \multirow{2}{*}{$\mathrm{PC}$} & \multicolumn{3}{|c|}{ MW } & \multirow{2}{*}{$\mathrm{PC}$} & \multicolumn{3}{|c|}{ MW } & \multirow{2}{*}{$\mathrm{PC}$} & \multicolumn{3}{|c|}{ MW } \\
\hline & & $\varphi=0.35$ & $\varphi=0.5$ & $\varphi=0.909$ & & $\varphi=0.35$ & $\varphi=0.5$ & $\varphi=0.909$ & & $\varphi=0.35$ & $\varphi=0.5$ & $\varphi=0.909$ \\
\hline$w$ & 0.4558 & - & - & - & 0.4853 & - & - & - & 0.5137 & - & - & - \\
\hline$y$ & - & 0.5014 & 0.5014 & 0.5014 & - & 0.5339 & 0.5339 & 0.5339 & - & 0.5651 & 0.5651 & 0.5651 \\
\hline $\bar{\sigma}$ & - & 0.4646 & 0.4646 & 0.4646 & - & 0.4947 & 0.4947 & 0.4947 & - & 0.5236 & 0.5236 & 0.5236 \\
\hline$\varepsilon$ & - & 1.0792 & 1.0792 & 1.0792 & - & 1.0793 & 1.0793 & 1.0793 & - & 1.0793 & 1.0793 & 1.0793 \\
\hline$K$ & 2.1860 & $-5.7 \%$ & $-5.7 \%$ & $-5.7 \%$ & 2.1599 & $-5.7 \%$ & $-5.7 \%$ & $-5.7 \%$ & 2.1121 & $-5.7 \%$ & $-5.7 \%$ & $-5.7 \%$ \\
\hline $\mathrm{L}$ & 1.50 & $-7.3 \%$ & $-7.3 \%$ & $-7.3 \%$ & 1.40 & $-7.3 \%$ & $-7.3 \%$ & $-7.3 \%$ & 1.30 & $-7.3 \%$ & $-7.3 \%$ & $7.3 \%$ \\
\hline$C^{L}($ for $e=b)$ & 0.4558 & $-61.5 \%$ & $-45.0 \%$ & $0.0 \%$ & 0.4853 & $-61.5 \%$ & $-45.0 \%$ & $0.0 \%$ & 0.5137 & $-61.5 \%$ & $-45.0 \%$ & $0.0 \%$ \\
\hline$C^{L}($ for $e=\varepsilon)$ & 0.4919 & $1.8 \%$ & $1.7 \%$ & $1.6 \%$ & 0.5238 & $1.8 \%$ & $1.75 \%$ & $1.6 \%$ & 0.5544 & $1.8 \%$ & $1.7 \%$ & $1.6 \%$ \\
\hline$C^{K}$ & 1.0817 & $-10.8 \%$ & $-13.0 \%$ & $-19.1 \%$ & 0.8939 & $-10.8 \%$ & $-13.0 \%$ & $-19.1 \%$ & 0.7517 & $-10.8 \%$ & $-13.0 \%$ & $-19.1 \%$ \\
\hline$u$ & 0 & $\begin{array}{c}0.1061 \\
(0.1414)\end{array}$ & $\begin{array}{c}0.1061 \\
(0.1414)\end{array}$ & $\begin{array}{c}0.1061 \\
(0.1414)\end{array}$ & 0 & $\begin{array}{c}0.0991 \\
(0.1416)\end{array}$ & $\begin{array}{c}0.0991 \\
(0.1416)\end{array}$ & $\begin{array}{c}0.0991 \\
(0.1416)\end{array}$ & 0 & $\begin{array}{c}0.0920 \\
(0.1415)\end{array}$ & $\begin{array}{c}0.0920 \\
(0.1415)\end{array}$ & $\begin{array}{c}0.0920 \\
(0.1415)\end{array}$ \\
\hline$\tau^{L}$ & 0 & 0.0131 & 0.0188 & 0.0341 & 0 & 0.0132 & 0.0188 & 0.0342 & 0 & 0.0132 & 0.0188 & 0.0342 \\
\hline$\tau^{\pi}$ & 0 & 0.0656 & 0.0938 & 0.1705 & 0 & 0.0658 & 0.0940 & 0.1709 & 0 & 0.0658 & 0.0940 & 0.1719 \\
\hline $\begin{array}{l}\% \text { of employed } \\
\text { workers for which } \\
\quad C^{L}{ }_{M W} \geq C_{P C}^{L}\end{array}$ & - & 100.00 & 100.00 & 75.94 & - & 100.00 & 100.00 & 75.62 & - & 100.00 & 100.00 & 75.93 \\
\hline$L I$ & 2.7350 & $-3.5 \%$ & $-2.6 \%$ & $-0.2 \%$ & 2.2649 & $-3.5 \%$ & $-2.6 \%$ & $-0.25 \%$ & 1.9082 & $-3.5 \%$ & $-2.6 \%$ & $-0.25 \%$ \\
\hline $\begin{array}{l}\text { Post tax- and - } \\
\text { transfers } L S\end{array}$ & 0.6056 & $2.2 \%$ & $3.1 \%$ & $5.7 \%$ & 0.6064 & $2.2 \%$ & $3.1 \%$ & $5.7 \%$ & 0.6072 & $2.2 \%$ & $3.1 \%$ & $5.7 \%$ \\
\hline
\end{tabular}

Notes: Numbers in bold imply exogenously set policy variables. Also, the MW columns present the equilibrium values of the various variables or, wherever applicable, their percentage changes from the PC case. 
Review of Economic Analysis 1 (2019) 1-38

Table 3d: Comparative static results with respect to $\sigma$ when capital income is exempt from taxation $(\lambda=0.30, \gamma=0.2)$

\begin{tabular}{|c|c|c|c|c|c|c|c|c|c|c|c|c|}
\hline \multirow[b]{3}{*}{ Variable } & \multicolumn{4}{|c|}{$\sigma=2$} & \multicolumn{4}{|c|}{$\sigma=0.9$} & \multicolumn{4}{|c|}{$\sigma=0.33$} \\
\hline & \multirow[b]{2}{*}{$\mathrm{PC}$} & \multicolumn{3}{|c|}{ MW } & \multirow{2}{*}{$\mathrm{PC}$} & \multicolumn{3}{|c|}{ MW } & \multirow[b]{2}{*}{ PC } & \multicolumn{3}{|c|}{ MW } \\
\hline & & $\varphi=0.35$ & $\varphi=0.5$ & $\varphi=0.769$ & & $\varphi=0.35$ & $\varphi=0.5$ & $\varphi=0.769$ & & $\varphi=0.35$ & $\varphi=0.5$ & $\varphi=0.769$ \\
\hline$w$ & 0.4788 & - & & - & 0.4853 & - & & - & 0.4870 & - & & - \\
\hline$y$ & - & 0.6224 & 0.6224 & 0.6224 & - & 0.6309 & 0.6309 & 0.6309 & - & 0.6331 & 0.6331 & 0.6331 \\
\hline $\bar{\sigma}$ & - & 0.5049 & 0.5049 & 0.5049 & - & 0.5114 & 0.5114 & 0.5114 & - & 0.5127 & 0.5127 & 0.5127 \\
\hline$\varepsilon$ & - & 1.2327 & 1.2327 & 1.2327 & - & 1.2337 & 1.2337 & 1.2337 & - & 1.2349 & 1.2349 & 1.2349 \\
\hline$K$ & 3.5376 & $-9.8 \%$ & $-9.8 \%$ & $-9.8 \%$ & 2.1599 & $-15.0 \%$ & $-15.0 \%$ & $-15.0 \%$ & 1.6431 & $-17.6 \%$ & $-17.6 \%$ & $-17.6 \%$ \\
\hline$L$ & 1.40 & $-18.9 \%$ & $-18.9 \%$ & $-18.9 \%$ & 1.40 & $-18.9 \%$ & $-18.9 \%$ & $-18.9 \%$ & 1.40 & $-19.0 \%$ & $-19.0 \%$ & $-19.0 \%$ \\
\hline$C^{L}($ for $e=b)$ & 0.4788 & $-54.5 \%$ & $-35.0 \%$ & $0.0 \%$ & 0.4853 & $-54.5 \%$ & $-35.0 \%$ & $0.0 \%$ & 0.4870 & $-54.5 \%$ & $-34.5 \%$ & $0.0 \%$ \\
\hline$C^{L}($ for $e=\varepsilon)$ & 0.5902 & $4.6 \%$ & $4.2 \%$ & $3.6 \%$ & 0.5987 & $4.4 \%$ & $4.0 \%$ & $3.2 \%$ & 0.6014 & $4.2 \%$ & $3.8 \%$ & $-3.0 \%$ \\
\hline$C^{K}$ & 1.0953 & $-24.2 \%$ & $-29.4 \%$ & $-38.7 \%$ & 0.8939 & $-29.1 \%$ & $-35.3 \%$ & $-46.4 \%$ & 0.8174 & $-31.2 \%$ & $-37.9 \%$ & $-49.8 \%$ \\
\hline$u$ & 0 & $\begin{array}{c}0.2393 \\
(0.3419) \\
\end{array}$ & $\begin{array}{c}0.2393 \\
(0.3419) \\
\end{array}$ & $\begin{array}{c}0.2393 \\
(0.3419) \\
\end{array}$ & 0 & $\begin{array}{c}0.2400 \\
(0.3429) \\
\end{array}$ & $\begin{array}{c}0.2400 \\
(0.3429) \\
\end{array}$ & $\begin{array}{c}0.2400 \\
(0.3429) \\
\end{array}$ & 0 & $\begin{array}{c}0.2410 \\
(0.3443) \\
\end{array}$ & $\begin{array}{c}0.2410 \\
(0.3443) \\
\end{array}$ & $\begin{array}{c}0.2410 \\
(0.3443) \\
\end{array}$ \\
\hline$\tau^{L}$ & 0 & 0.0355 & 0.0507 & 0.0779 & 0 & 0.0404 & 0.0577 & 0.0887 & 0 & 0.0426 & 0.0608 & 0.0936 \\
\hline$\tau^{\pi}$ & 0 & 0.1773 & 0.2533 & 0.3897 & 0 & 0.2018 & 0.2883 & 0.4436 & 0 & 0.2129 & 0.3042 & 0.4679 \\
\hline $\begin{array}{c}\% \text { of employed } \\
\text { workers for which } \\
\quad C^{L}{ }_{M W} \geq C_{P C}^{L}\end{array}$ & - & 100.00 & 100.00 & 80.89 & - & 100.00 & 97.77 & 69.53 & - & 100.00 & 94.69 & 63.35 \\
\hline$L I$ & 2.2345 & $-8.5 \%$ & $-6.0 \%$ & $-1.5 \%$ & 2.2649 & $-8.9 \%$ & $-6.5 \%$ & $-2.1 \%$ & 2.2725 & $-9.2 \%$ & $-6.75 \%$ & $-2.4 \%$ \\
\hline $\begin{array}{l}\text { Post tax- and -transfers } \\
L S\end{array}$ & 0.5229 & $4.9 \%$ & $7.8 \%$ & $13.1 \%$ & 0.6064 & $6.8 \%$ & $9.6 \%$ & $14.7 \%$ & 0.6441 & $7.3 \%$ & $10.1 \%$ & $15.2 \%$ \\
\hline
\end{tabular}

Notes: Numbers in bold imply exogenously set policy variables. Also, the MW columns present the equilibrium values of the various variables or, wherever applicable, their percentage changes from the PC case. 
ECONOMIDES, MOUTOS Worker Heterogeneity and Popularity of Minimum Wage

Table 3e: Comparative static results with respect to $\sigma$ when capital income is exempt from taxation $(\lambda=0.10, \gamma=0.5)$

\begin{tabular}{|c|c|c|c|c|c|c|c|c|c|c|c|c|}
\hline \multirow{3}{*}{ Variable } & \multicolumn{4}{|c|}{$\sigma=2$} & \multicolumn{4}{|c|}{$\sigma=0.9$} & \multicolumn{4}{|c|}{$\sigma=0.33$} \\
\hline & \multirow{2}{*}{ PC } & \multicolumn{3}{|c|}{ MW } & \multirow{2}{*}{$\mathrm{PC}$} & \multicolumn{3}{|c|}{ MW } & \multirow{2}{*}{$\mathrm{PC}$} & \multicolumn{3}{|c|}{ MW } \\
\hline & & $\varphi=0.35$ & $\varphi=0.5$ & $\varphi=0.909$ & & $\varphi=0.35$ & $\varphi=0.5$ & $\varphi=0.909$ & & $\varphi=0.35$ & $\varphi=0.5$ & $\varphi=0.35$ \\
\hline$w$ & 0.4788 & - & - & - & 0.4853 & - & - & - & 0.4870 & - & - & - \\
\hline$y$ & - & 0.5267 & 0.5267 & 0.5267 & - & 0.5339 & 0.5339 & 0.5339 & - & 0.5357 & $\mathbf{0 . 5 3 5 7}$ & 0.5357 \\
\hline $\bar{\sigma}$ & - & 0.4881 & 0.4881 & 0.4881 & - & 0.4947 & 0.4947 & 0.4947 & - & 0.4962 & 0.4962 & 0.4962 \\
\hline$\varepsilon$ & - & 1.0790 & 1.0790 & 1.0790 & - & 1.0793 & 1.0793 & 1.0793 & - & 1.0797 & 1.0797 & 1.0797 \\
\hline$K$ & 3.5376 & $-3.7 \%$ & $-3.7 \%$ & $-3.7 \%$ & 2.1599 & $-5.7 \%$ & $-5.7 \%$ & $-5.7 \%$ & 1.6431 & $-6.8 \%$ & $-6.8 \%$ & $-6.8 \%$ \\
\hline$L$ & 1.40 & $-7.3 \%$ & $-7.3 \%$ & $-7.3 \%$ & 1.40 & $-7.35 \%$ & $-7.35 \%$ & $-7.35 \%$ & 1.40 & $-7.4 \%$ & $-7.4 \%$ & $-7.4 \%$ \\
\hline$C^{L}($ for $e=b)$ & 0.4788 & $-61.5 \%$ & $-45.0 \%$ & $0.0 \%$ & 0.4853 & $-61.5 \%$ & $-45.0 \%$ & $0.0 \%$ & 0.4870 & $-61.5 \%$ & $-45.0 \%$ & $0.0 \%$ \\
\hline$C^{L}($ for $e=\varepsilon)$ & 0.5166 & $1.8 \%$ & $1.7 \%$ & $1.4 \%$ & 0.5238 & $1.7 \%$ & $1.6 \%$ & $1.4 \%$ & 0.5258 & $1.7 \%$ & $1.6 \%$ & $1.3 \%$ \\
\hline$C^{K}$ & 1.0953 & $-7.9 \%$ & $-9.3 \%$ & $-13.0 \%$ & 0.8939 & $-9.4 \%$ & $-11.0 \%$ & $-15.4 \%$ & 0.8174 & $-10.0 \%$ & $-11.8 \%$ & $-16.5 \%$ \\
\hline$u$ & 0 & $\begin{array}{c}0.0988 \\
(0.1411) \\
\end{array}$ & $\begin{array}{c}0.0988 \\
(0.1411) \\
\end{array}$ & $\begin{array}{c}0.0988 \\
(0.1411) \\
\end{array}$ & 0 & $\begin{array}{c}0.0991 \\
(0.1416) \\
\end{array}$ & $\begin{array}{c}0.0991 \\
(0.1416) \\
\end{array}$ & $\begin{array}{c}0.0991 \\
(0.1416) \\
\end{array}$ & 0 & $\begin{array}{c}0.0995 \\
(0.1422) \\
\end{array}$ & $\begin{array}{c}0.0995 \\
(0.1422) \\
\end{array}$ & $\begin{array}{c}0.0995 \\
(0.1422) \\
\end{array}$ \\
\hline$\tau^{L}$ & 0 & 0.0219 & 0.0312 & 0.0568 & 0 & 0.0240 & 0.0342 & 0.0622 & 0 & 0.0249 & 0.0356 & 0.0647 \\
\hline$\tau^{\pi}$ & 0 & 0.0437 & 0.0624 & 0.1135 & 0 & 0.0479 & 0.0685 & 0.1245 & 0 & 0.0498 & 0.0711 & 0.1293 \\
\hline $\begin{array}{c}\% \text { of employed } \\
\text { workers for which } \\
C^{L}{ }_{M W} \geq C_{P C}^{L}\end{array}$ & - & 98.10 & 81.81 & 46.85 & - & 94.59 & 75.71 & 41.40 & - & 91.93 & 72.26 & 38.34 \\
\hline$L I$ & 2.2345 & $-3.9 \%$ & $-3.2 \%$ & $-1.4 \%$ & 2.2649 & $-4.1 \%$ & $-3.4 \%$ & $-1.7 \%$ & 2.2725 & $-4.2 \%$ & $-3.6 \%$ & $-1.85 \%$ \\
\hline $\begin{array}{l}\text { Post tax- and - } \\
\text { transfers } L S\end{array}$ & 0.5229 & $1.0 \%$ & $1.7 \%$ & $3.7 \%$ & 0.6064 & $1.6 \%$ & $2.3 \%$ & $4.2 \%$ & 0.6441 & $1.8 \%$ & $2.45 \%$ & $4.25 \%$ \\
\hline
\end{tabular}

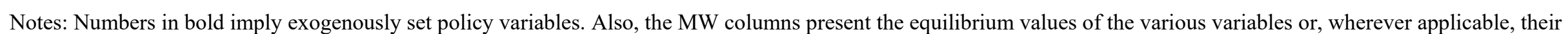
percentage changes from the PC case. 
Table 3f: Comparative static results with respect to $\sigma$ when capital income is exempt from taxation $(\lambda=0.10, \gamma=1)$

\begin{tabular}{|c|c|c|c|c|c|c|c|c|c|c|c|c|}
\hline \multirow{3}{*}{ Variable } & \multicolumn{4}{|c|}{$\sigma=2$} & \multicolumn{4}{|c|}{$\sigma=0.9$} & \multicolumn{4}{|c|}{$\sigma=0.33$} \\
\hline & \multirow{2}{*}{$\mathrm{PC}$} & \multicolumn{3}{|c|}{ MW } & \multirow{2}{*}{$\mathrm{PC}$} & \multicolumn{3}{|c|}{ MW } & \multirow{2}{*}{ PC } & \multicolumn{3}{|c|}{ MW } \\
\hline & & $\varphi=0.35$ & $\varphi=0.5$ & $\varphi=0.909$ & & $\varphi=0.35$ & $\varphi=0.5$ & $\varphi=0.909$ & & $\varphi=0.35$ & $\varphi=0.5$ & $\varphi=0.909$ \\
\hline$w$ & "0.4788 & - & - & - & 0.4853 & - & - & - & 0.4870 & - & - & - \\
\hline$y$ & - & 0.5267 & 0.5267 & 0.5267 & - & 0.5339 & 0.5339 & 0.5339 & - & 0.5357 & 0.5357 & 0.5357 \\
\hline$\tilde{\sigma}$ & - & 0.4881 & 0.4881 & 0.4881 & - & 0.4947 & 0.4947 & 0.4947 & - & 0.4962 & 0.4962 & 0.4962 \\
\hline$\varepsilon$ & - & 1.0790 & 1.0790 & 1.0790 & - & 1.0793 & 1.0793 & 1.0793 & - & 1.0797 & 1.0797 & 1.0797 \\
\hline$K$ & 3.5376 & $-3.7 \%$ & $-3.7 \%$ & $-3.7 \%$ & 2.1599 & $-5.7 \%$ & $-5.7 \%$ & $-5.7 \%$ & 1.6431 & $-6.8 \%$ & $-6.8 \%$ & $-6.8 \%$ \\
\hline$L$ & 1.40 & $-7.3 \%$ & $-7.3 \%$ & $-7.3 \%$ & 1.40 & $-7.35 \%$ & $-7.35 \%$ & $-7.35 \%$ & 1.40 & $-7.4 \%$ & $-7.4 \%$ & $-7.4 \%$ \\
\hline$C^{L}($ for $e=b)$ & 0.4788 & $-61.5 \%$ & $-45.0 \%$ & $0.0 \%$ & 0.4853 & $-61.5 \%$ & $-45.0 \%$ & $0.0 \%$ & 0.4870 & $-61.5 \%$ & $-45.0 \%$ & $0.0 \%$ \\
\hline$C^{L}($ for $e=\varepsilon)$ & 0.5166 & $1.7 \%$ & $1.5 \%$ & $1.2 \%$ & 0.5238 & $1.6 \%$ & $1.5 \%$ & $1.1 \%$ & 0.5258 & $1.6 \%$ & $1.4 \%$ & $1.1 \%$ \\
\hline$C^{K}$ & 1.0953 & $-6.9 \%$ & $-7.9 \%$ & $-10.6 \%$ & 0.8939 & $-8.2 \%$ & $-9.4 \%$ & $-12.4 \%$ & 0.8174 & $-8.7 \%$ & $-9.9 \%$ & $-13.2 \%$ \\
\hline$u$ & 0 & $\begin{array}{c}0.0988 \\
(0.1411) \\
\end{array}$ & $\begin{array}{c}0.0988 \\
(0.1411) \\
\end{array}$ & $\begin{array}{c}0.0988 \\
(0.1411) \\
\end{array}$ & 0 & $\begin{array}{c}0.0991 \\
(0.1416) \\
\end{array}$ & $\begin{array}{c}0.0991 \\
(0.1416) \\
\end{array}$ & $\begin{array}{c}0.0991 \\
(0.1416) \\
\end{array}$ & 0 & $\begin{array}{c}0.0995 \\
(0.1422) \\
\end{array}$ & $\begin{array}{c}0.0995 \\
(0.1422) \\
\end{array}$ & $\begin{array}{c}0.0995 \\
(0.1422) \\
\end{array}$ \\
\hline$\tau^{L}$ & 0 & 0.0309 & 0.0441 & 0.0802 & 0 & 0.0330 & 0.0471 & 0.0857 & 0 & 0.0339 & 0.0484 & 0.0881 \\
\hline$\tau^{\pi}$ & 0 & 0.0309 & 0.0441 & 0.0802 & 0 & 0.0330 & 0.0471 & 0.0857 & 0 & 0.0339 & 0.0484 & 0.0881 \\
\hline $\begin{array}{l}\% \text { of employed workers } \\
\text { for which } C_{M W}^{L} \geq C_{P C}^{L}\end{array}$ & - & 82.37 & 61.10 & 29.49 & - & 77.98 & 56.69 & 26.39 & - & 75.01 & 53.89 & 24.67 \\
\hline$L I$ & 2.2345 & $-4.4 \%$ & $-3.9 \%$ & $-2.6 \%$ & 2.2649 & $-4.5 \%$ & $-4.1 \%$ & $-2.9 \%$ & 2.2725 & $-4.6 \%$ & $-4.2 \%$ & $-3.1 \%$ \\
\hline $\begin{array}{c}\text { Post tax- and -transfers } \\
L S\end{array}$ & 0.5229 & $0.5 \%$ & $1.0 \%$ & $2.4 \%$ & 0.6064 & $1.1 \%$ & $1.6 \%$ & $2.9 \%$ & 0.6441 & $1.3 \%$ & $1.8 \%$ & $3.0 \%$ \\
\hline
\end{tabular}

Notes: Numbers in bold imply exogenously set policy variables. Also, the MW columns present the equilibrium values of the various variables or, wherever applicable, their percentage changes from the PC case. 


\section{ECONOMIDES, MOUTOS Worker Heterogeneity and Popularity of Minimum Wage}

However, this conclusion would not necessarily survive if we introduced a fixed disutility of leisure into our framework - e.g. by writing the individual (per-period) utility functions as $U=\ln C-\vartheta$, where $\vartheta$ stands for the fixed (and common across individuals) disutility of work. In such a case, and as long as $\vartheta$ is very close to the $\ln C$ which low-ability workers would receive in the PC case, it is possible that low ability workers would enjoy higher utility if the MW regime forced them out of work but received even meager unemployment benefits (e.g. $\phi<0.20$ ). Coupling these individual utility functions with social welfare functions which give progressively lower weight to higher income individuals (e.g. Atkinson, 1970; Sen, 1977), it is possible to construct cases where the increased utility accruing to all workers more than offsets the loss of utility suffered by capitalists, and, as a result, social welfare increases. Nevertheless, since a proper treatment of this issue should allow for labour supply responses along both the extensive and intensive margin, we do not pursue this issue further here.

If policy was determined according to the wishes of the majority under a comprehensive linear tax, Tables 2a-2d revealed that the MW regime would not win political support unless the welfare support provided to the unemployed was small. However, with progressive taxes in place, Tables 3a-3f revealed that a majority in favour of the MW regime could be formed even when the support provided to the unemployed was substantial.

However, political scientists have long argued that unadulterated, fully participatory, majoritarian democracy describes no actual political system - rather, the translation of resources into influence occurs in highly institutionalized environments that amplify some voices and mute others (Ferguson, 1995; Bartels, 2008). For example, Gilens and Page (2014), on the basis of an analysis of 1,779 cases in U.S. policymaking between 1981 and 2002 , found that economic elites and organized groups representing business interests have substantial independent impacts on U.S. government policy, while average citizens (as captured by the median voter model) and mass-based interest groups have little or no independent influence. ${ }^{43}$

The above imply that it may be more interesting to enquire whether labour organizations or political parties interested in furthering "working-class interests" would be in favour of the minimum wage policy if the perceived outcomes were the ones presented in Tables 2 and 3.

If the objective of labour unions was to maximize the absolute value of (after-tax) income accruing to workers (both employed and unemployed), denoted by $L I$ in the Tables, then the MW regime would be detrimental to their interests. ${ }^{44}$ However, it is possible that labour

${ }^{43}$ A famous case of pork-barrel politics in which business groups influenced policy is the SmootHawley tariff of 1930 (Schattschneider, 1935), despite the vociferous oppositions of many economists as evidenced in the appeal (drafted by Paul H. Douglas and signed by 1,028 economists) to President Herbert Hoover urging him to veto the Smoot-Hawley tariff.

${ }^{44}$ We note that we have followed standard economic discourse and assumed the existence of rational actors with stable, coherent, and autonomous preferences, which are not affected by the social 
organizations may be willing to pay a price in terms of foregone income in order to gain in power relative to the capitalists. An index of the relative power of labour may be the share of after-tax income accruing to (employed and unemployed) workers - denoted by $L S$. Since the MW regime leads to a rise in $L S$ (and a corresponding decline in the share received by capitalists), organized labour may be willing to pursue "inefficient" policies, which nonetheless may be instrumental in tilting future political power toward workers as the relative resources available to capitalists to influence other facets of economic and social policy become smaller. In this vein, Acemoglu and Robinson (2013) have argued that the politico-economic environment may have features whose removal may ex-ante look efficient (e.g. minimum wage legislation) if one does not take into account how their removal may affect the future political equilibrium. But, if their removal is associated with a shift of power away from labour, while enhancing the power of established (non-competitive) business interests and political elites, it can lead to emergence of policies that generate greater efficiency losses than those entailed by the policies which were removed. The upshot of these considerations is that minimum wages may be perceived by organized labour not only as way to further the interests of (some sections) of the working class at the expense of aggregate efficiency, but as a harbinger of efficiency enhancing policies (e.g. public education) due to the increased political power of the working class.

\section{Concluding Remarks}

We have constructed a model with heterogenous labour ability in which the imposition of a (binding) MW generates large disemployment effects. These effects arise not only because firms respond to the wage increase - relative to the static perfectly competitive benchmark by moving upwards along a given labour demand curve, but also due to inward shifts of the labour demand curve as savers respond to decreases in the (net of taxes) rate of return on their savings by saving less, thus reducing the economy's steady-state capital stock. Nevertheless, the large, long-run, declines in aggregate output, consumption, and the capital stock implied by this model do not render MW legislation unattractive for large segments of employed

context. Gintis (2016) and Hoff and Stiglitz (2016) provide wide-ranging discussions of how social influences on preferences and cognition can influence the set of mental models upon which individuals can draw when making decisions, and how the resulting social rationality can lead to political action that matches better with observed behaviour than individual rationality. Participating in labour unions is one specific instance in which the resulting enculturation may alter individuals' preferences and the lenses through which they make sense of the economic and political environment (Aghion et al., 2011). Incorporating these issues into our analysis is beyond the scope of the present paper. 


\section{ECONOMIDES, MOUTOS Worker Heterogeneity and Popularity of Minimum Wage}

workers, as long as they do not have to provide generous welfare support to the low-ability workers that the MW prevents them from finding employment.

Tax structure plays an important role in generating political support for the MW regime. A progressive tax structure can assure political support for the MW regime in cases when moderate welfare support for the unemployed would not be politically viable under proportional taxation. However, even progressive taxation would not be sufficient to create a political majority for the MW if welfare support is very generous.

With linear taxation we have shown that it is possible for the after-tax incomes of all employed workers to increase under a minimum-wage regime but only if the unemployed receive welfare payments significantly smaller than what their incomes would be in the competitive case. In other words, it is impossible for the minimum-wage regime to increase the after-tax aggregate income of (employed and unemployed) workers. The effects of minimum-wage legislation thus match with what Stigler (1970) termed Director's Law according to which public interventions are made for the primary benefit of the middle classes, and financed with taxes which are borne in considerable part by the (rich) capitalists and workers of the lowest ability who become unemployed. This message remains intact to a great extent even when non-linear (e.g. progressive) tax structures are considered.

The paper takes as given the country's existing arrangements regarding its tax structure and social welfare system. ${ }^{45}$ It also does not enquire as to whether there exist other ways of increasing the incomes of workers and which can avoid the inefficiency of MW-generated unemployment. For example, in the United States, the Earned Income Tax Credit (EITC) provides a refundable tax credit to lower income working families through the tax system, and its goal is to increase the after-tax income of lower earning taxpayers, primarily those with children, while incentivizing work. It is clear that such policy interventions do not result in increases either in the gross or in the after-tax wage rate of employed workers. This implies that if the workers' goal is to increase the wage they earn ${ }^{46}$, or to force firms to pay them a higher wage rate, then, from their point of view the MW is preferable to the EITC. Moreover, as long as workers' organizations aim at increasing their (relative) power or influence over

${ }^{45}$ It also ignores the possibility that the large disemployment effects of moderately binding minimum wages inherent in our model could, in principle, be partly countered - in the presence of sufficient political power - by public employment programmes. Assuming that these (low-ability) employees are remunerated at the legislated minimum $(y)$, and that the goods/services produced by these programmes provide some utility to households, it may be possible to construct cases for which this type of "policy complementarity" increases the political viability of minimum wages.

${ }^{46}$ Recent discussions during the latest US presidential elections focused on "takers" and "givers", the former being citizens (but not corporations) who are recipients of government support. Recipients of government programmes like the EITC, despite being described as providing support to the "deserving poor", may be classified in the public's perception as "takers" whose privileges may be withdrawn at any point in time. In contrast, a rise in worker incomes caused by the imposition of a MW generates no such public perception. 
Review of Economic Analysis 1 (2019) 1-38

policy, they will strive for increases in the post-tax-and-transfers labour share - which is something they can achieve through the MW institution, but not through policies like the EITC or through other "rewarding work"- type policies, e.g. employment subsidies targeted at the unskilled (see, e.g. Phelps, 1997; Sinn, 2000).

\section{References:}

Acemoglu, D. (2009), Introduction to Modern Economic Growth, Princeton University Press, Princeton, NJ.

Acemoglu, D. and J.A. Robinson (2013), Economics versus Politics: Pitfalls of Policy Advice , Journal of Economic Perspectives, 27(2), 173-92. DOI: 10.1257/jep.27.2.173

Adam, A. and T. Moutos (2011), A politico-economic analysis of minimum wages and wage subsidies $\quad$ Economics Letters, vol. 110(3), 171-173. https://doi.org/10.1016/j.econlet.2010.11.029

Aghion, P., Y. Algan, and P. Cahuc (2011), Civil Society And The State: The Interplay Between Cooperation And Minimum Wage Regulation, Journal of the European Economic Association, European Economic Association, vol. 9(1), 3-42. https://doi.org/10.1111/j.1542-4774.2010.01004.x

Allegretto, S. A., A. Dube, and M. Reich (2011), Do minimum wages really reduce teen employment? Accounting for heterogeneity and selectivity in state panel data , Industrial Relations, 50 (2), 204-240. https://doi.org/10.1111/j.1468-232X.2011.00634.x

Allen, S., (1987), Taxes, redistribution, and the minimum wage: a theoretical analysis , Quarterly Journal of Economics 102 (3), 477-490. https://www.jstor.org/stable/1884214

Alvaredo, F., A. Atkinson, T. Piketty and E. Saez (2013), The Top 1 Percent in International and Historical Perspective, Journal of Economic Perspectives, 27, 3-20. DOI: 10.1257/jep.27.3.3

Antras, P. (2004), Is the U.S. Aggregate Production Function Cobb-Douglas? New Estimates of the Elasticity of Substitution, Contributions to Macroeconomics, 4, article 4.

Atkinson, A. B. (1970), On the Measurement of Inequality , Journal of Economic Theory, 2, 244-263. https://doi.org/10.1016/0022-0531(70)90039-6

Bartels, L. M. (2008), Unequal Democracy: The Political Economy of the New Gilded Age, New York: Russell Sage Foundation and Princeton University Press.

Berndt, E. (1976), Reconciling Alternative Estimates of the Elasticity of Substitution , Review of Economics and Statistics, 58:1, pp. 59-68.

Boadway, R., and K. Cuff, (2001), A minimum wage can be welfare-improving and employment enhancing , European Economic Review 45, 553-576. https://doi.org/10.1016/S0014-2921(00)00066-0

Brown, C., G. Curtis, and A. Kohen, (1982), The Effect of the Minimum Wage on Employment and Unemployment, Journal of Economic Literature, 20, (2), 487-528. 
ECONOMIDES, MOUTOS Worker Heterogeneity and Popularity of Minimum Wage

Card, D. and A. Krueger, (1994), Minimum Wages and Employment: A Case Study of the Fast-Food Industry in New Jersey and Pennsylvania , American Economic Review, vol. 84, no. 4, pp. 772-793. https://www.jstor.org/stable/2118030

Card, D. and A. Krueger, (1995), Myth and Measurement: The New Economics of the Minimum Wage. Princeton, NJ: Princeton University Press.

Card, D. and A. Krueger, (2000), Minimum Wages and Employment: A Case Study of the Fast-Food Industry in New Jersey and Pennsylvania: Reply , American Economic Review, vol. 90, no. 5, pp. 1397-1420. DOI: 10.1257/aer.90.5.1362

Chamley, C. (1986), Optimal Taxation of Capital Income in General Equilibrium with Infinite Lives , Econometrica, 54, 607-622.

Creedy, J. (1977), Pareto and the distribution of income, Review of Income and Wealth, 23, pp. 405-411.

Dickens, R., and A. Manning (2004), Spikes and spill-overs: The impact of the national minimum wage on the wage distribution in a low-wage sector , Economic Journal, 114(494), C95-C101. https://doi.org/10.1111/j.0013-0133.2003.00198.x

Dube, A., T. William Lester, and M. Reich, (2010), Minimum Wage Effects Across State Borders: Estimates Using Contiguous Counties, Review of Economics and Statistics, vol. 92, no. 4, pp. 945-964. https://www.jstor.org/stable/40985804

Economides, G., and T. Moutos, (2016), Can Minimum Wages Raise Workers' Incomes in the Long Run? , Journal of Public Economic Theory, vol. 18 (6), 961-978. https://doi.org/10.1111/jpet.12216

Ferguson, T. (1995), Golden Rule: The Investment Theory of Party Competition and the Logic of Money-Driven Political Systems, Chicago: The University of Chicago Press.

Gabaix, X. (2016), Power Laws in Economics: An Introduction , Journal of Economic Perspectives, 30, 1, 185-206.

Gilens, M., and B. I. Page (2014), Testing Theories of American Politics: Elites, Interest Groups, and Average Citizens , Perspectives on Politics, vol. 12, 564-581.

Gintis, H., (2016), Homo Ludens: Social rationality and political behavior , Journal of Economic Behavior \& Organization, 126, 95-109. https://doi.org/10.1016/j.jebo.2016.01.004

Guesnerie, R., and K. Roberts, (1987), Minimum wage legislation as a second best policy , European Economic Review 31, 490-498. https://doi.org/10.1016/0014-2921(87)90067-5

Hoff, K., and J. Stiglitz (2016), Striving for balance in economics: Towards a theory of the social determination of behavior, Journal of Economic Behavior \& Organization, 126, 25-57. https://doi.org/10.1016/j.jebo.2016.01.005

Judd, K., (1985), Redistributive Taxation in a Simple Perfect Foresight Model, Journal of Public Economics, 28, 59-83. https://doi.org/10.1016/0047-2727(85)90020-9 
Review of Economic Analysis 1 (2019) 1-38

Lee, D., and E. Saez, (2012), Optimal minimum wage policy in competitive labor markets, Journal of Public Economics, 96, 739-749. https://doi.org/10.1016/j.jpubeco.2012.06.001

Machin, S., and A. Manning, (1997), Minimum wages and economic outcomes in Europe , European Economic Review, 41(3-5), 733-742. https://doi.org/10.1016/S0014$\underline{\text { 2921(97)00032-9 }}$

Manning, A., (1995), How Do We Know That Wages are Too High?, The Quarterly Journal of Economics, 110(4), 1111-25. https://doi.org/10.2307/2946650

Manning, A., (2003), Monopsony in Motion: Imperfect Competition in Labor Markets, Princeton University Press, Princeton, NJ.

Marceau, N., and R. Boadway, (1994), Minimum wage legislation and unemployment insurance, Scandinavian Journal of Economics 96, 67-81.

Mirrlees, J., (1971), An Exploration in the Theory of Optimum Income Taxation, Review of Economic Studies, 38, 175-208. https://doi.org/10.2307/2296779

Newmark, D., and W. Wascher, (2000), Minimum Wages and Employment: A Case Study of the Fast-Food Industry in New Jersey and Pennsylvania: Comment. , American Economic Review, 90(5), 1362-1396. https://www.jstor.org/stable/2677855

Newmark, D., and W. Wascher, (2008), Minimum Wages, Cambridge, MA: The MIT Press.

Neumark, D., J. I. Salas, and W. Wascher, (2014), Revisiting the minimum wageemployment debate: Throwing out the baby with the bathwater, Industrial and Labor Relations Review, 67 (3), 608-648. https://doi.org/10.1177/00197939140670S307

Phelps, E., (1997), Rewarding Work: How to Restore Participation and Self-Support to Free Enterprise, Harvard University Press, Cambridge, MA.

Rebitzer, J., and L. Taylor, (1995), The consequences of minimum wage laws: some new theoretical ideas , Journal of Public Economics 56, 245-255. https://doi.org/10.1016/0047-2727(93)01411-3

Robinson, J., (1933), The Economics of Imperfect Competition. MacMillan, London.

Saint- Paul, G., (2000), The Political Economy of Labour Market Institutions, Oxford University Press, New York.

Schattschneider, E.E., (1935), Politics, Pressures and the Tariff, New York: Prentice-Hall.

Sen, A. (1997), On Economic Inequality, Oxford University Press, 2nd edition. Oxford, UK.

Sinn, H.-W., (2000), The threat to the German welfare state , Atlantic Economic Journal, 28(3), 279-294.

Sobel, R., (1999), Theory and Evidence on the Political Economy of the Minimum Wage , Journal of Political Economy, 107(4), 761-785.

Stigler, G., J., (1970), Director's Law of Public Income Redistribution, Journal of Law and Economics, 13, 1-10. https://www.jstor.org/stable/724835

Webb, S., (1912), The Economic Theory of a Legal Minimum Wage, Journal of Political Economy, 20, 973-98. https://www.jstor.org/stable/1820545 